Chicago-Kent College of Law

Scholarly Commons @ IIT Chicago-Kent College of Law

All Faculty Scholarship

Faculty Scholarship

January 2010

\title{
Valuing Intellectual Property: An Experiment
}

Christopher J. Buccafusco

IIT Chicago-Kent College of Law, cbuccafusco@kentlaw.iit.edu

C. Sprigman

Follow this and additional works at: https://scholarship.kentlaw.iit.edu/fac_schol

Part of the Evidence Commons, and the Intellectual Property Law Commons

\section{Recommended Citation}

Christopher J. Buccafusco \& C. Sprigman, Valuing Intellectual Property: An Experiment, 96 Cornell L. Rev. 1 (2010).

Available at: https://scholarship.kentlaw.iit.edu/fac_schol/147

This Article is brought to you for free and open access by the Faculty Scholarship at Scholarly Commons @ IIT Chicago-Kent College of Law. It has been accepted for inclusion in All Faculty Scholarship by an authorized administrator of Scholarly Commons @ IIT Chicago-Kent College of Law. For more information, please contact jwenger@kentlaw.iit.edu, ebarney@kentlaw.iit.edu. 


\title{
VALUING INTELLECTUAL PROPERTY: AN EXPERIMENT
}

\author{
Christopher Buccafusco $\mathcal{E}$ Christopher Sprigman†
}

I. The Behavioral Economics of Intellectual Property

Law .................................... 5

A. Classical Economics and Intellectual Property...... 5

B. Behavioral Challenges to the Rational Choice

Model: The Endowment Effect ............... 6

1. The Strength of the Endowment Effect............ 9

2. Psychological Mechanisms Behind the Endowment Effect................................ 11

C. The Endowment Effect in Legal Scholarship....... 13

D. Our Hypothesis ............................ 15

II. Modeling an IP Market $\ldots \ldots \ldots \ldots \ldots \ldots \ldots \ldots \ldots . \ldots \ldots$

A. The Contest: "Eyes Closed" .................. 19

1. Contest "Eyes Closed" Method ................... 19

2. Contest "Eyes Closed" Results ................... 20

B. The Contest: "Eyes Open" .................. 21

C. The Lottery: "Blind" .......................... 23

1. Lottery Method .......................... 23

2. Lottery Results ........................ 24

III. Understanding Creators' Behavior: InTERPRETING

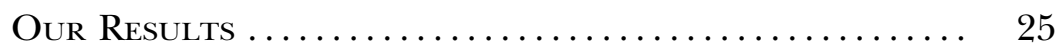

IV. Implications for Intellectual Property LaW and Policy ...................................... 31

A. Do the Endowment Effects We Observe Lead to Inefficiency? ............................

B. The Debate Between Property Rules and Liability

Rules .....................................

$\dagger$ Assistant Professor, Chicago-Kent College of Law, and Professor, University of Virginia School of Law, respectively. This research has been supported by grants from the John Olin Foundation and the University of Virginia Law School Foundation. The authors wish to thank Meg Scalia, J. McClendon, Kate Ranganath, Sean FitzGerald, Joseph Carlasare, Arthur Sadiq, and Tim Cook for their superb research assistance. The authors are grateful for helpful comments received from John Cacioppo, Dennis Crouch, Deven Desai, Dan Gilbert, Chris Guthrie, Paul Heald, Robert Heverly, Ariel Katz, Mark Lemley, Jonathan Masur, Greg Mitchell, Dotan Oliar, Jeff Rachlinski, Jennifer Rothman, Bobbie Spellman, Simon Stern, Stephanie Stern, Katherine Strandburg, and participants in workshops at the University of Toronto Faculty of Law, the University of Pennsylvania Law School, the Sloan School of Management at the Massachusetts Institute of Technology, the University of Illinois College of Law, the Loyola Law School, Los Angeles, and the 2009 Intellectual Property Scholars' Conference. 
C. The Effects of Royalties and Formalities on IP

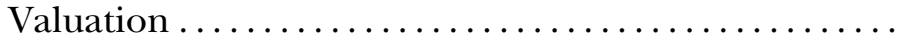

D. Behavioral Biases and the Market Failure Theory of

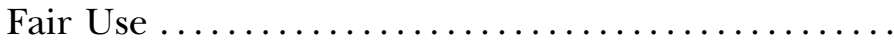

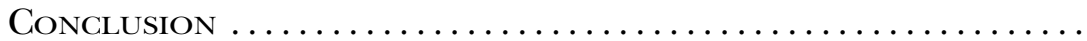

Over the past few decades, important new research in behavioral psychology and experimental economics has challenged fundamental social-scientific assumptions about individual rationality and the efficient functioning of markets. ${ }^{1}$ The "rational actor" model of neoclassical economics, which assumes that people have stable preferences and make decisions that maximize their utility, is eroding in favor of a more nuanced and empirically robust view of human decision making as "boundedly rational." According to this view, individuals' preferences are often highly unstable such that they value the same goods differently depending on the way the goods are presented to them. In addition, due to a number of cognitive and affective biases, people often fail to choose the things that make them most happy. ${ }^{2}$

Recently, legal scholars ${ }^{3}$ and even some courts ${ }^{4}$ have applied these findings to the law, causing them to rethink essential features of tort, ${ }^{5}$ contract, ${ }^{6}$ property, ${ }^{7}$ and criminal law, ${ }^{8}$ among other areas. Surprisingly, however, there has been relatively little discussion of this research's implications for intellectual property (IP) law. ${ }^{9}$ We say sur-

1 See Russell B. Korobkin \& Thomas S. Ulen, Law and Behavioral Science: Removing the Rationality Assumption from Law and Economics, 88 CALIF. L. REv. 1051, 1054-55 (2000).

2 See John Bronsteen, Christopher Buccafusco \& Jonathan S. Masur, Welfare as Happiness, 98 GEO. L.J. 1583, 1586 (2010).

3 See Cass R. Sunstein, Introduction to Behavioral Law and Economics 1, 1 (Cass R. Sunstein ed., 2000).

4 See O Centro Espirita Beneficiente Uniao do Vegetal v. Ashcroft, 389 F.3d 973, 1016 (10th Cir. 2004) (McConnell, J., concurring).

5 See John Bronsteen, Christopher Buccafusco \& Jonathan S. Masur, Hedonic Adaptation and the Settlement of Civil Lawsuits, 108 Colum. L. REv. 1516, 1516 (2008).

6 See Russell Korobkin, The Status Quo Bias and Contract Default Rules, 83 Cornell L. REv. 608, 611-12 (1998).

7 See, e.g., Jonathan Remy Nash \& Stephanie M. Stern, Property Frames, 87 WASH. U. L. REv. 449 (2010).

8 See John Bronsteen, Christopher Buccafusco \& Jonathan Masur, Happiness and Punishment, 76 U. CHI. L. REv. 1037, 1037 (2009).

9 For exceptions, see infra note 85. IP scholarship is increasingly turning its attention to empirical social science methods. Some of these papers rely on empirical research from other disciplines to draw out the implications for IP while others have performed novel empirical tests of an increasing number of IP's fundamental assumptions. For the former, see Jeanne Fromer, A Psychology of Intellectual Property, 104 Nw. U. L. REv. (forthcoming 2010); Gregory N. Mandel, Left-Brain Versus Right-Brain: Competing Conceptions of Creativity in Intellectual Property Law (Temp. Univ. Legal Studies Res. Paper Series, Research Paper No. 2010-8), available at http://papers.ssrn.com/sol3/papers.cfm?abstract_id=15882 14. For the latter variety, see Paul J. Heald, Property Rights and the Efficient Exploitation of Copyrighted Works: An Empirical Analysis of Public Domain and Copyrighted Fiction Bestsellers, 92 Minn. L. Rev. 1031 (2008); Gregory N. Mandel, Patently Non-Obvious: Empirical Demonstra- 
prisingly because IP, perhaps more than any other substantive area of law, is grounded in the rational actor model that undergirds classical economics. ${ }^{10}$ According to the economic account of IP, the monopolistic rights granted by copyrights and patents exist to provide economic incentives to creators. Furthermore, the initial distribution of IP rights, the formalities for the vesting of those rights, and the rules regarding fair use all derive from IP law's assumption that individual actors with stable preferences will maximize both personal and social utility through efficient bargaining. ${ }^{11}$ In previous research, we have begun to challenge some of these ideas, especially the idea that strong IP protection is necessary to incentivize creativity. ${ }^{12}$ In this Article, we report on an experiment that undermines another such idea-that creators and purchasers of IP have stable, wealth-maximizing preferences.

Perhaps the most important contribution of the behavioral research to date is the discovery that individuals' valuations of goods or states of affairs is highly dependent on the way those goods are framed. ${ }^{13}$ Whereas classical economic theory assumes that the value a person attaches to an item is endogenous (i.e., based on the person's

tion that the Hindsight Bias Renders Patent Decisions Irrational, 67 Oнiо Sт. L.J. 1391 (2006); David L. Schwartz, Practice Makes Perfect? An Empirical Study of Claim Construction Reversal Rates in Patent Cases, 107 Mich. L. Rev. 223 (2008).

10 See William M. Landes \& Richard A. Posner, The Economic Structure of Intellectual Property Law 3-4 (2003); John P. Conley \& Christopher S. Yoo, Nonrivalry and Price Discrimination in Copyright Economics, 157 U. PA. L. REv. 1801, 1802 (2009) (noting that although arguments about copyright have settled into polar extremes, "both sides generally frame the arguments in largely economic terms"). Of course, there are also noneconomic justifications for IP rights. This Article does not enter into the debate between economic and noneconomic justifications that are, at least to some extent, rival. Rather, for our purposes here, we work within the framework of the economic justification, which is the principal rationale supporting IP rights in the United States. See generally Margaret Jane Radin, Market-Inalienability, 100 HARv. L. REv. 1849 (1987) (offering alternatives to the prevailing economic justifications).

11 Mazer v. Stein, 347 U.S. 201, 219 (1954) ("The economic philosophy behind the clause empowering Congress to grant patents and copyrights is the conviction that encouragement of individual effort by personal gain is the best way to advance public welfare through the talents of authors and inventors in 'Science and useful Arts.'”); LANDES \& Posner, supra note 10, at 11-36; Shyamkrishna Balganesh, Foreseeability and Copyright Incentives, 122 Harv. L. Rev. 1569, 1579 (2009).

12 See Christopher J. Buccafusco, On the Legal Consequences of Sauces: Should Thomas Keller's Recipes Be Per Se Copyrightable?, 24 Cardozo Arts \& EnT. L.J. 1121, 1123 (2007); Dotan Oliar \& Christopher Sprigman, There's No Free Laugh (Anymore): The Emergence of Intellectual Property Norms and the Transformation of Stand-Up Comedy, 94 VA. L. REv. 1787, 1790 (2008); Kal Raustiala \& Christopher Sprigman, The Piracy Paradox: Innovation and Intellectual Property in Fashion Design, 92 VA. L. Rev. 1687, 1691 (2006); see also Rebecca Tushnet, Economies of Desire: Fair Use and Marketplace Assumptions, 51 WM. \& MARY L. Rev. 513, 521 (2009) ("Creativity, as lived, is more than a response to incentives, working from fixed and random preferences.”).

13 See Samuel Issacharoff, Can There Be a Behavioral Law and Economics?, 51 VAND. L. Rev. 1729, 1735 (1998); Russell Korobkin, The Endowment Effect and Legal Analysis, 97 Nw. U. L. REV. 1227, 1229 (2003). 
internal preferences), a mountain of survey and experimental data have shown that people attach substantially higher value to goods they own as compared to goods they are considering purchasing. ${ }^{14}$ People are reluctant to part with their property, and the amount that they are willing to accept (WTA) to sell it far exceeds the amount that others are willing to pay (WTP) for it. This WTA/WTP gap has been termed the "endowment effect" and has been detected for an astounding variety of forms of property. ${ }^{15}$

As yet, however, no study has explored the existence of an endowment effect for property that, like IP, (1) was actually created by the owners and (2) is nonrival (i.e., consumption by one person does not prevent consumption by another). In this Article, we present an experiment that demonstrates a substantial valuation asymmetry between authors of poems and potential purchasers of them. As we explain, we created a market for poems modeled after a market for licensing IP. The observed differences in valuation indicate that IP licensing markets may be substantially less efficient than previously believed. Our results suggest that (1) the preferences of IP creators, owners, and purchasers are unstable and dependent on the initial distribution of property rights in creative works, and that (2) large gaps arise between WTP and WTA even though the poems are nonrival property and the contemplated alienation of the property is therefore only partial.

Our findings suggest that private transactions in creative goods may face significant transaction costs arising from cognitive biases. These biases in turn drive the price that creators and owners of IP are likely to demand considerably higher than buyers will, on average, be willing to pay. This discovery does not mean, of course, that transactions in IP will not take place-we see such transactions happening every day. Our research suggests, however, both that IP transactions may occur at a frequency that is significantly suboptimal ${ }^{16}$ and that the baleful effect of cognitive and affective biases is likely to be more serious for transactions in works of relatively low commercial value or for which no well-established custom or pattern helps to inform valuation. These results have considerable implications for the structuring of IP rights, IP formalities, IP licensing, and fair use.

Part I of this Article describes the orthodox account of IP law and its basis in classical economic theory. It then discusses research on the endowment effect, its causes, and its application to other areas of legal scholarship. It concludes with a description of our hypothesis. Part II

14 For a review, see Korobkin, supra note 13, at 1230-42.

15 See id.

16 By "suboptimal," we mean that parties will engage in fewer mutually beneficial transactions because of endowment effects than they would in the absence of such biases. 
describes our experiment, including the methods and results of three different experimental conditions. In short, we find a substantial valuation asymmetry between creators and purchasers of IP, with creators valuing their work more than twice as highly as potential buyers do. Importantly, we were unable to diminish the asymmetry either by using transaction intermediaries or by providing additional market information. Part III discusses our results and the likely psychological mechanisms that drive them. Part IV addresses the implications of our results for IP law and theory and explores possible legal solutions to the inefficiencies that the endowment effect seems to create.

The Behavioral Economics of Intellectual

Property LAW

\section{A. Classical Economics and Intellectual Property}

IP law relies heavily on legal rights structured as "property rules," which establish an owner's ability to exclude others, as distinguished from "liability rules," which permit access to an owner's property but mandate some payment to the rightsholder. ${ }^{17}$ The decision to formulate most IP rules as providing rights to exclude is based largely on a belief that individuals engaged in market transactions will do a better job relative to the government (e.g., courts, agencies, and legislatures) at setting prices for access to IP. ${ }^{18}$ If the law gives rightsholders a right to exclude, private negotiations set the price of access. If, on the other hand, the law establishes a liability rule, then some public rulemaker-most likely a legislature, agency, or court-will have to determine the price of access.

IP law's deeply rooted preference for market price setting is based on an even more fundamental presumption that underlies neoclassical economic theory in general: people act as rational agents who make choices based on their own stable and well-defined preferences. ${ }^{19}$ In particular, economic theory posits that when making decisions, people rationally weigh the utility they will derive from different

17 For the canonical formulation of property and liability rules, see Guido Calabresi \& A. Douglas Melamed, Property Rules, Liability Rules, and Inalienability: One View of the Cathedral, 85 Harv. L. Rev. 1089, 1089-93 (1972).

18 See Landes \& Posner, supra note 10, at 414 ("Markets and property rights go hand in hand. Property rights provide the basic incentives for private economic activity and also the starting point for transactions whereby resources are shifted to their most valuable use.”); Robert P. Merges, Contracting into Liability Rules: Intellectual Property Rights and Collective Rights Organizations, 84 CALIF. L. Rev. 1293, 1308 (1996) (“[Intellectual Property rights] liability rules are set by Congress through compulsory licensing schemes and are not precisely-tailored valuations.").

19 Daniel Kahneman et al., The Endowment Effect, Loss Aversion, and Status Quo Bias, $5 \mathrm{~J}$. Econ. Persp. 193, 193 (1991). 
choices and assign monetary values to the options by anticipating the utility these choices will provide. This supposition, which has been labeled the "rational choice model," is so fundamental to the structure of IP law that it is often simply taken for granted. ${ }^{20}$ Although the right to exclude that a copyright or patent conveys often gives initial entitlement in a property right to a party poorly situated to exploit that right (i.e., the work's author (copyright) or inventor (patent)), the law does not concern itself overmuch with this possibility. It presumes, instead, that parties will negotiate to transfer property rights in creative goods to those who might best exploit them. Negotiation is, of course, potentially burdened by a number of different transaction costs, but at the abstract level of economic thinking that drives most intellectual property policymaking, private negotiations are presumed to be efficacious in most instances. ${ }^{21}$ This confidence is bolstered by an unreflective ${ }^{22}$ application of the Coase Theorem, which holds that in the absence of transaction costs, the initial entitlement of property rights will not affect their final allocation ${ }^{23}$ because efficient transactions will occur such that property rights will end up in the hands of the party who values them the most. ${ }^{24}$ This prediction itself leans heavily on the rational choice model-i.e., it relies on the assumption that preferences are stable and that transacting parties will value an asset or right the same whether they are considering buying or selling it. ${ }^{25}$

B. Behavioral Challenges to the Rational Choice Model: The Endowment Effect

In recent decades, interdisciplinary research in the social sciences has challenged many of the core assumptions of the rational choice model of classical economics. ${ }^{26}$ Instead of acting like rational utility maximizers, people are beset by a number of systematic cognitive and emotional biases that lead them to act in ways that depart substantially

20 See Note, Designing the Public Domain, 122 Harv. L. Rev. 1489, 1496 (2009) ("The standard economic theory of intellectual property includes the simplifying assumption that humans are selfish rational actors.”).

21 To the extent that transaction costs are recognized in orthodox IP scholarship, they tend to be those costs associated with bargaining, holdouts, and information rather than the costs associated with irrationalities. See Merges, supra note 18, at 1328-40 (discussing costs associated with bargaining, valuation, and detection).

22 We say "unreflective" because of the tendency to overlook Coase's main insightthat transaction costs are almost never zero and are usually considerably positive. See Robert D. Cooter, Coase Theorem, in 1 The New Palgrave: A Dictionary of Economics 457, 458 (John Eatwell et al. eds., The Stockton Press 1987).

23 R. H. Coase, The Problem of Social Cost, 3 J.L. \& Econ. 1, 8 (1960).

24 Id. at 7-8.

25 See Stephanie Jacques, The Endowment Effect and the Coase Theorem, 74 Am. J. Agric. ECON. 1316, 1316 (1992).

26 See Korobkin \& Ulen, supra note 1, at 1053-54. 
from the rational choice model's predictions. Research has shown that people do a poor job of predicting what will make them happy, ${ }^{27}$ that they rely on a variety of quasi-rational heuristic shortcuts when making decisions, ${ }^{28}$ and that the situations people find themselves in profoundly affect the choices that they make. ${ }^{29}$ Most importantly for IP law is the considerable evidence that people's preferences and their valuations of those preferences are unstable and subject to substantial manipulation by situational variables. ${ }^{30}$ Accordingly, small changes in the context of a decision can greatly affect the extent to which people value a particular good or property right. ${ }^{31}$

Perhaps the most significant variable affecting valuation of a good is ownership of the good itself. The first evidence of a systematic ownership bias emerged from surveys in the 1970s that attempted to place a monetary value on public goods such as environmental protection. ${ }^{32}$ Investigators noticed that subjects had a tendency to demand a higher selling price for a commodity that they owned than they were willing to pay to acquire the same good as a buyer. ${ }^{33}$ Additionally, the discrepancy was not only present consistently, but often quite large. For instance, one study found that people demanded on average $\$ 143$ to sell a hunting permit that they owned yet were only willing to pay $\$ 31$ to acquire that same hunting permit. ${ }^{34}$ Thus, there appeared to be a significant discrepancy between the maximum price that people were willing to pay to acquire a certain right (WTP) and the minimum price they were willing to accept to give up that same right (WTA). The researchers posited that the difference in ask versus bid prices arose from an "endowment effect"-i.e., a tendency for people to

27 For a review, see Bronsteen, Buccafusco \& Masur, supra note 2, at 1586.

28 See Christoph Engel \& Gerd Gigerenzer, Law and Heuristics: An Interdisciplinary Venture, in Heuristics AND THE LAw 1, 1-4 (G. Gigerenzer \& C. Engel eds., 2006).

29 See Daniel Kahneman \& Amos Tversky, Choices, Values, and Frames, in CHoices, Values, And Frames 1, 2 (Daniel Kahneman \& Amos Tversky eds., 2000).

30 See, e.g., Gretchen B. Chapman \& Eric J. Johnson, Incorporating the Irrelevant: Anchors in Judgments of Belief and Value, in Heuristics and Biases: The Psychology of Intuitive Judgment 120, 120-21 (Thomas Gilovich et al. eds., 2002) (describing how people's valuations of gambles are affected by irrelevant cues).

31 See Richard Thaler, Toward a Positive Theory of Consumer Choice, 1 J. Econ. BeHAv. \& ORG. 39, 45 (1980) (showing that people respond differently to a situation referred to as a "cash discount" than to an identical one labeled a "credit card surcharge"); Amos Tversky \& Daniel Kahneman, The Framing of Decisions and the Psychology of Choice, 211 Scr. 453, 453 (1981) (showing that people's preferences for an identical situation change depending on whether people imagine saving lives or allowing people to die).

32 See Korobkin, supra note 13, at 1232.

33 David R. Mandel, Beyond Mere Ownership: Transaction Demand as a Moderator of the Endowment Effect, 88 Organizational Behav. \& Hum. Decision Processes 737, 737 (2002).

34 Ziv Carmon \& Dan Ariely, Focusing on the Forgone: How Value Can Appear So Different to Buyers and Sellers, 27 J. Consumer Res. 360, 360 (2000). 
value that which they own more highly than the opportunity to obtain goods or services of equivalent value. ${ }^{35}$

This type of behavior is highly problematic for classical economic theory. The rational choice model predicts that if an individual decides that the marginal value of some good is $\$ 5$, then given the opportunity, she will purchase it for any price up to that amount. Similarly, if she owns the good and is offered any amount of money above $\$ 5$, she will happily sell it. The early evidence of an endowment effect, which indicated that an individual's preferences changed depending on conditions of ownership, challenged this assumption.

Following these initial observations and the formulation of the endowment effect, economists and psychologists embarked on a variety of experiments aimed at testing the existence and strength of this anomaly. Daniel Kahneman, Richard Thaler, and colleagues conducted the initial laboratory experiments by simulating markets using student volunteers. ${ }^{36}$ In the best-known early experiment, the researchers gave coffee mugs emblazoned with the university's logo to half of the subjects in a classroom and directed all of the subjects to examine the mugs (whether it was their own or their neighbor's). The students to whom the mugs were given were asked to indicate the minimum price at which they would be willing to sell their mug, while the students without mugs were asked to indicate how much they would be willing to pay to purchase one. ${ }^{37}$ The investigators attempted to keep the valuations honest by informing the participants that one out of every four subject pairs would be randomly selected as a "real" transaction-i.e., those buyers that bid higher than the market clearing price would purchase a mug and those owners who valued it lower than the clearing price would give theirs up. ${ }^{38}$ According to classical economic theory, the valuations assigned by the sellers and the buyers should have been similar, and approximately half of the

35 Thaler, supra note 31, at 43-47. As Kathryn Zeiler notes, the use of the term "endowment effect" for the observation of a WTA/WTP gap creates biases of its own as it imports an explanation of the gap into the description of the behavior-i.e., that the valuation gap is due to sellers' attachment to the good based in their ownership of it. See Kathryn Zeiler, The Endowment Effect: Implications of Recent Empirical Developments for Legal Theory 10 n.32 (Oct. 14, 2008) (unpublished manuscript) (on file with authors). We choose to employ the phrase through this Article because it has been widely adopted by most commentators on the literature. Importantly, however, we join Zeiler in resisting the temptation to use the "endowment effect" as fully explanatory of the WTA/WTP gap. Instead, our experimental design inquires into the underlying psychological mechanisms that might motivate the gap.

36 Daniel Kahneman, Jack L. Knetsch \& Richard H. Thaler, Experimental Tests of the Endowment Effect and the Coase Theorem, 98 J. PoL. Econ. 1325, 1329 (1990).

37 Id. at $1330-31$.

38 Id. at 1330. 
mugs should have changed hands. ${ }^{39}$ After conducting several rounds of the experiment, however, the investigators found that the median selling price was more than twice the median buying price and that only about a quarter of the mugs were exchanged. ${ }^{40}$

This experiment, along with others reported by Kahneman and his colleagues, provided suggestive evidence of the presence of an endowment effect. As a result, social scientists began conducting experiments to both test the limits of the endowment effect and determine whether and to what extent the endowment effect affects particular types of transactions. Although it is not necessary to detail every aspect of this research, ${ }^{41}$ a review a several of the major findings is beneficial.

\section{The Strength of the Endowment Effect}

First, the magnitude of the endowment effect appears to vary depending on the type of good involved. A survey of endowment effect experiments found that the discrepancy between WTP and WTA tends to be highest for public and nonmarket goods such as health and safety measures, lower for ordinary private goods such as mugs and candy bars, and lowest for objects associated with monetary payments, such as lottery tickets. ${ }^{42}$ Importantly, however, even when it comes to goods such as lottery tickets-for which the calculation of a "rational" value should be straightforward-an endowment effect seems to exist. For instance, in one experiment, researchers distributed raffle tickets to half of the members of an undergraduate classroom and gave the other half an opportunity to purchase a ticket to participate in the raffle for $\$ 2 .{ }^{43}$ Additionally, the researchers asked those who initially received a ticket whether they would be willing to sell the ticket for $\$ 2 .{ }^{44}$ While 50 percent of subjects with the opportunity to buy into the raffle for $\$ 2$ chose to do so, only $24 \%$ of the peo-

39 Although different subjects might rationally value the mugs at different amounts, there was no reason to think that those who valued the mugs more highly were in one group rather than the other. Because the mugs were distributed randomly, the students valuing the mugs above the mean should have been equally distributed between buyers and sellers, thereby leading to an exchange of approximately half of the mugs.

40 Kahneman, Knetsch \& Thaler, supra note 36, at 1332.

41 For a comprehensive account of many of the experiments that researchers have carried out, see generally Korobkin, supra note 13. For an analysis of a survey of the experiments, see generally John K. Horowitz \& Kenneth E. McConnell, A Review of WTA/WTP Studies, 44 J. Envtl. Econ. \& Mgmt. 426 (2002).

42 Horowitz \& McConnell, supra note 41, at 433-34. Most relevant to our paper, an endowment effect has been shown for information, another nonrival good. See Daphne R. Raban \& Sheizaf Rafaeli, The Effect of Source Nature and Status on the Subjective Value of Information, 57 J. Ам. Soc'y for Info. ScI. \& TEсH. 321 (2006).

43 Jack L. Knetsch \& J.A. Sinden, Willingness to Pay and Compensation Demanded: Experimental Evidence of an Unexpected Disparity in Measures of Value, 99 Q.J. Econ. 507, 510 (1984).

44 Id. 
ple who already possessed a lottery ticket accepted the offer to sell it for $\$ 2 .{ }^{45}$ In other words, while half of the potential buyers valued the raffle ticket at a sum equal to or exceeding $\$ 2,76 \%$ of the original owners placed a value on their ticket that was more than $\$ 2 .{ }^{46}$ These results suggest that even when a subject is only endowed with a probabilistic opportunity to receive some good, she is likely to value the chance more highly than she otherwise would.

In addition to the type of good, the subject's relationship to the entitlement significantly affects the intensity of the endowment effect. ${ }^{47}$ In one set of studies, members of a group who believed they received goods as a result of their superior performance on a test valued the goods more highly than those who had merely obtained the goods by chance. ${ }^{48}$ Thus, the experimenters concluded (1) that subjects who believed that they had earned the goods attached more value to them than did subjects who had merely been given the goods and (2) that the manner by which an owner obtains an object generally affects how highly the owner values it. ${ }^{49}$

Related to the issue of the endowment effect's magnitude is the unresolved issue regarding the extent to which market experience can substantially or even entirely diminish the endowment effect. If overvaluation is simply the result of irrational, heuristic processing on the part of owners of goods, it seems reasonable to think that consistent experience in the relevant market will provide a signal to owners indicating the good's actual value. Indeed, several experiments have found evidence that the endowment effect shrinks as an owner gains market experience. ${ }^{50}$

Importantly, however, some experiments question the ability of market experience to limit the endowment effect. First, several exper-

\footnotetext{
$45 \quad I d$. at 511.

46 Id

47 See Jochen Reb \& Terry Connolly, Possession, Feelings of Ownership and the Endowment Effect, 2 Judgment \& Decision Making 107, 107 (2007) (“[T] here is more to the endowment effect than simple factual ownership of an object.").

48 George Loewenstein \& Samuel Issacharoff, Source Dependence in the Valuation of Objects, 7 J. Behav. Decision Making 157, 160 (1994).

$49 I d$. at 165 . Other factors influencing the magnitude of endowment effects include duration of ownership and whether the good is valued primarily for use or for exchange. See Kahneman, Knetsch \& Thaler, supra note 36, at 1342; Mandel, supra note 33, at 745. There is reason to believe that owners do not anticipate the same sense of loss for goods they are holding for exchange relative to goods they are planning to use. As a result, owners value goods held for exchange less highly than they do goods that they use and, thus, are more likely to exchange the former than the latter.

50 John A. List, Does Market Experience Eliminate Market Anomalies?, 118 Q.J. Econ. 41, 41-42 (2003) [hereinafter List, Market Experience]; see also Don L. Coursey, John L. Hovis \& William D. Schulze, The Disparity Between Willingness to Accept and Willingness to Pay Measures of Value, 102 Q.J. Econ. 679, 680 (1987); John A. List, Neoclassical Theory Versus Prospect Theory: Evidence from the Marketplace, 72 EconomETricA 615, 615-16 (2004).
} 
iments have failed to find that market experience leads to a decrease in the endowment effect. ${ }^{51}$ More work is to be done on this point, but for the moment it seems fair to say that although the idea that valuation divergences will decrease as subjects become familiar with a market may be "intuitively compelling, . . . the evidence is weak." 52 Second, market experience appears to limit the endowment effect only in markets featuring substitutable goods. Increased experience in a market that consists of goods with readily available substitutes (e.g., coffee mugs or candy bars) may result in a convergence of the values that owners and buyers attribute to a certain good. Where there are no close substitutes for the good, however, valuation divergences are likely to persist regardless of market experience. ${ }^{53}$ Creative goods are highly differentiated and tend to lack close substitutes, thus constraining the ability of market experience to resolve valuation anomalies. Third, even if the endowment effect decreases with market experience, many parties involved in real-world transactions have no significant market experience and will not gain any. ${ }^{54}$ This is true of many transactions in creative goods where authors, inventors, and other rightsholders often lack market experience. Finally, it is important to note that the behaviors associated with the endowment effect have been studied almost exclusively in the context of individual decision making. Accordingly, it is difficult to predict how they might be altered by group decision making or decisions where nonowners exercise oversight. ${ }^{55}$

\section{Psychological Mechanisms Behind the Endowment Effect}

Although the evidence for the existence of an endowment effect is robust, a number of important questions remain unanswered. Most importantly, the precise psychological mechanisms underlying the effect are not fully understood. Researchers have suggested a number of explanations. Some have asserted that the endowment effect is an example of a broader "ownership effect." ${ }^{56}$ The ownership effect posits that because people tend to view themselves in a positive light, and because they see objects they own as extensions of themselves, people are prone to find objects more attractive when they own them

51 See, e.g., Kahneman, Knetsch \& Thaler, supra note 36, at 1332.

52 Horowitz \& McConnell, supra note 41, at 442.

53 See Jason F. Shogren et al., Resolving Differences in Willingness to Pay and Willingness to Accept, 84 Am. Econ. Rev. 255, 256-58 (1994).

54 See id.

55 See Jennifer Arlen et al., Endowment Effects Within Corporate Agency Relationships, $31 \mathrm{~J}$. Legal Stud. 1, 18-22 (2002) (finding diminished endowment effects in principal-agent relationship); Andreas Glöckner et al., The Endowment Effect in Groups With and Without Strategic Incentives 6-7 (Max Planck Inst. for Research on Collective Goods, Paper No. 35, 2009), available at http://ssrn.com/abstract $=1500309$.

56 Mandel, supra note 33 , at 737. 
than when they do not. ${ }^{57}$ According to one group of researchers, "People may demand a lot for their [goods] because they actually like them, and they may like them simply because they are theirs." 58 The ownership effect helps explain experimental results demonstrating more pronounced endowment effects for goods that are easy to associate with the self or that people believe they have earned. ${ }^{59}$

Another explanation of the endowment effect focuses on the pervasive human aversion to loss. ${ }^{60}$ Specifically, most people value the acquisition of a good or right much less than they fear losing that same good or right. ${ }^{61}$ As a result, people have a "strong tendency to remain at the status quo, because the disadvantages of leaving it loom larger than advantages." 62 Thus, owners of a right typically demand more money to forfeit it than they would be willing to pay to purchase it in an effort to compensate for the discomfort that they would feel after giving up the right. ${ }^{63}$ These feelings may be particularly acute in studies involving lottery tickets where subjects contemplate the regret they would feel if they sold what turned out to be the winning ticket. ${ }^{64}$ People are fearful of regret, and therefore they are often willing to pay substantial premiums to avoid it. ${ }^{65}$

Similarly, the differences between buyer and seller valuations may stem from variations in cognitive and emotional processes. When considering a transaction, buyers and sellers tend to focus on different aspects of the entitlement. ${ }^{66}$ Specifically, while buyers tend to focus their attention on what they are forgoing to acquire the good or right (e.g., money), the seller tends to focus on the benefits that are en-

57 See James K. Beggan, On the Social Nature of Nonsocial Perception: The Mere Ownership Effect, 62 J. Personality \& Soc. Psychol. 229, 235 (1992).

58 Carey K. Morewedge et al., Bad Riddance or Good Rubbish? Ownership and Not Loss Aversion Causes the Endowment Effect, 45 J. Experimental Soc. Psychol. 947, 948 (2009).

59 See id. at 950.

60 See Ian Bateman et al., Testing Competing Models of Loss Aversion: An Adversarial Collaboration, 89 J. Pub. Econ. 1561, 1562 (2005); Amos Tversky \& Daniel Kahneman, Loss Aversion in Riskless Choice: A Reference-Dependent Model, 106 Q.J. Econ. 1039, 1054 (1991).

61 Tversky \& Kahneman, supra note 60, at 1041. Additionally, researchers have found that people experience a feeling of loss even when they never actually had possession of a particular good or right. For instance, in one experiment, it was found that consumers forced to choose between several options (e.g., which car to buy) experience a feeling of discomfort after they make their decision and even find the forgone options to be more attractive after they have given them up. See Ziv Carmon et al., Option Attachment: When Deliberating Makes Choosing Feel Like Losing, 30 J. Consumer Res. 15, 16 (2003).

62 Kahneman et al., supra note 19, at 197-98.

63 See Deborah A. Kermer et al., Loss Aversion Is an Affective Forecasting Error, 17 Psychol. Sci. 649, 649 (2006).

64 See Maya Bar-Hillel \& Efrat Neter, Why Are People Reluctant to Exchange Lottery Tickets?, 70 J. Personality \& Soc. Psychol. 17, 17 (1996).

65 See Daniel T. Gilbert et al., Looking Forward to Looking Backward: The Misprediction of Regret, 15 Psychol. Sci. 346, 346 (2004).

66 See Carmon \& Ariely, supra note 34, at 360. 
joyed through ownership of the item (e.g., the pleasure expected from use of a ticket to a sporting event). ${ }^{67}$ Consequently, while the buyer's willingness to pay tends to center around market values, the seller's valuation tends to include subjective value, thereby raising the price that the seller will demand to transfer the property.

\section{The Endowment Effect in Legal Scholarship}

In a recent review, Russell Korobkin argues that the endowment effect is "undoubtedly the most significant single finding from behavioral economics for legal analysis to date." 68 Considering the number of references to the phenomenon in legal literature-more than ninehundred law review articles mention the endowment effect ${ }^{69}$ - his assertion hardly seems unwarranted. Since its initial formulation, scholars have applied the endowment effect to a growing body of substantive and procedural legal fields encompassing most aspects of public and private law. ${ }^{70}$

Recognition of the systematic discrepancy between owner and purchaser valuations has caused legal scholars to reevaluate many areas of the law where Coasean bargaining has been influential. For example, scholars have suggested that the WTA/WTP gap might lead to inefficiencies in valuations of risks and losses in fields such as tort or environmental law. They have debated whether appropriate compensation for an increased risk of illness or disability is best measured by someone's willingness to pay to avoid the risk or the much higher amount of money that she would be willing to accept to confront the risk. ${ }^{71}$ In contract law, the attachment that parties may exhibit towards default or mandatory provisions might lead to inefficient bargaining. ${ }^{72}$ Recently, Richard Thaler and Cass Sunstein have developed an extensive normative argument-"libertarian paternal-

\footnotetext{
67 See id. at 365-66.

68 Korobkin, supra note 13, at 1229.

69 A search of the Journals and Law Reviews database (JLR) on Westlaw for "endowment effect" on August 31, 2010 returned 926 matches.

70 See Korobkin, supra note 13, at 1229.

71 See, e.g., Mark Geistfeld, Placing a Price on Pain and Suffering: A Method for Helping Juries Determine Tort Damages for Nonmonetary Injures, 83 CALIF. L. REv. 773, 775 (1995); Jack L. Knetsch, Biased Valuations, Damage Assessments, and Policy Choices: The Choice of Measure Matters, 63 Ecological Econ. 684, 684 (2007); Edward J. McCaffery, Daniel J. Kahneman \& Matthew L. Spitzer, Framing the Jury: Cognitive Perspectives on Pain and Suffering Awards, 81 VA. L. REv. 1341, 1342-44 (1995).

72 See Korobkin, supra note 6, at 609-10; Cass R. Sunstein, Switching the Default Rule, 77 N.Y.U. L. Rev. 106, 112 (2002). According to Sunstein, "Where the Coase Theorem blunders is in suggesting that no matter the initial allocation of the entitlement, people will bargain to the same result. The Coase Theorem fails to account for the fact that the initial allocation seems to create an endowment effect. When the endowment effect is at work, those who initially receive a legal right value it more than they would if the initial allocation had given the right to someone else." Id. (footnote omitted).
} 
ism"-to capitalize on the stickiness of default rules and encourage people to make welfare-maximizing choices while maintaining freedom of choice. ${ }^{73}$

The endowment effect's legal implications have been most richly explored in property law. ${ }^{74}$ The efficient use and transfer of land was at the center of Coase's initial insight, and thus it is no surprise that the behavioral challenges to the Coase Theorem focus on property. For Coase, the initial distribution of property rights is irrelevant in a world without transaction costs because parties will bargain until the property ends up in the hands of the highest-valuing user. This account supposes that parties' valuations are stable and endogenous. Behavioral evidence on the endowment effect, however, suggests that the initial distribution of rights plays a major role in constructing parties' valuations. Primary owners will tend to overvalue their property, and transactions will be inefficiently low-just as in Thaler's mug study. ${ }^{75}$ Accordingly, legal scholars have cast a critical eye on classical economic accounts of regulatory takings, ${ }^{76}$ adverse possession, ${ }^{77}$ and property remedies. ${ }^{78}$

Most important for this Article is an experiment conducted by Jeffrey Rachlinski and Forest Jourden. ${ }^{79}$ They noted that previous endowment effect studies confounded ownership of a property right with a property rule-style remedy that enabled owners to refuse to sell their rights if they so chose. Rachlinski and Jourden speculated that the choice to refuse to sell may be a "critical psychological component of ownership" and that manipulation of this component could substantially affect valuation. ${ }^{80}$ They presented subjects with scenarios describing property rights protected either by injunctive relief (property rules) or by damages remedies (liability rules) and asked buyers

73 See Richard H. Thaler \& Cass R. Sunstein, Nudge: Improving Decisions About Health, Wealth, and Happiness 4-6 (2008); Cass R. Sunstein \& Richard H. Thaler, Libertarian Paternalism Is Not an Oxymoron, 70 U. CHI. L. Rev. 1159, 1160-61 (2003).

74 See Jeremy A. Blumenthal, "To Be Human": A Psychological Perspective on Property Law, 83 Tul. L. Rev. 609, 630-31 (2009); Owen D. Jones \& Sarah F. Brosnan, Law, Biology, and Property: A New Theory of the Endowment Effect, 49 WM. \& MARY L. Rev. 1935, 1988 (2008); Korobkin, supra note 13, at 1256-66.

75 See Kahneman, Knetsch \& Thaler, supra note 36, at 1325-28.

76 William A. Fischel, The Offer/Ask Disparity and Just Compensation for Takings: A Constitutional Choice Perspective, 15 InT'L REv. L. \& Econ. 187, 187 (1995).

77 Jeffrey Evans Stake, The Uneasy Case for Adverse Possession, 89 GEo. L.J. 2419, 2456 (2001) (asserting that adverse possession should be approached with consideration to the fact that " $[\mathrm{b}] \mathrm{y}$ investing her will in the land, [the adverse possessor] develops an attachment that is critical to her identity").

78 See Nash \& Stern, supra note 7; Stephanie M. Stern, Residential Protectionism and the Legal Mythology of Home, 107 MicH. L. REv. 1093, 1095 (2009).

79 Jeffrey J. Rachlinski \& Forest Jourden, Remedies and the Psychology of Ownership, 51 VAND. L. REV. 1541 (1998).

$80 \quad I d$. at 1542. 
and sellers a question intended to elicit their valuation of the rights. ${ }^{81}$ An endowment effect was observed only when property rules protected the rights. ${ }^{82}$ According to the authors, these findings offer the law a valuable tool for promoting efficient trade-preference for liability rules-in the face of inefficiencies that the endowment effect creates. ${ }^{83}$ Because the ability to refuse sale plays a key role in a person's valuation of property, eliminating that ability can reduce the endowment effect. ${ }^{84}$

Although legal scholars are increasingly turning their attention to the endowment effect's implications for a variety of legal fields, relatively little attention has been paid to its likely impact on IP law. ${ }^{85}$ To help fill this lacuna, we performed the first test of the endowment effect in a setting intended to mirror an IP market.

\section{Our Hypothesis}

Despite more than two decades of empirical testing of the endowment effect, one area that has yet to be probed is whether the endowment effect extends to goods that an owner has created. In all previous experiments, the owners have either simply been given the goods that they are then asked to value or, occasionally, have done something to earn them. None of the previous experiments asked subjects to actually create an object and then value it. Our experiment is the first to do so.

Prior experimental evidence on the endowment effect-especially the studies documenting powerful endowment effects for "earned" goods-suggests that endowment effects might be particularly strong in the context of personally created goods. On the other hand, most but not all creative goods are nonrivalrous-transfer of rights in a creative work such as a poem, novel, screenplay, or even most photographs and other graphic arts does not deprive the origi-

$81 I d$. at $1561-66$.

$82 I d$. at 1566.

83 Id. at 1574

$84 I d$. at 1572 ("The power to refuse to sell a right seems to be psychologically important to ownership. Property is not truly owned if someone can willfully appropriate it upon payment of a fee."). For an argument that liability rules will create larger endowment effects than will property rules, see Daphna Lewinsohn-Zamir, The Choice Between Property Rules and Liability Rules Revisited: Critical Observations from Behavioral Studies, 80 TEx. L. Rev. 219, 254 (2001).

85 For exceptions, see Laura R. Bradford, Parody and Perception: Using Cognitive Research to Expand Fair Use in Copyright, 46 B.C. L. Rev. 705, 722-23 (2005); Frank P. Darr, Testing an Economic Theory of Copyright: Historical Materials and Fair Use, 32 B.C. L. Rev. 1027, 1046 (1991); Ben Depoorter, Technology and Uncertainty: The Shaping Effect on Copyright Law, 157 U. PA. L. Rev. 1831, 1853 (2009); Wendy J. Gordon, Trespass-Copyright Parallels and the HarmBenefit Distinction, 122 Harv. L. REv. F. 62, 69 (2009); Raymond Shih Ray Ku, Grokking Grokster, 2005 WIs. L. REv. 1217, 1261; Alfred C. Yen, Restoring the Natural Law: Copyright as Labor and Possession, 51 Oнiо Sт. L.J. 517, 545 (1990). 
nal rightsholder of possession of a copy of the work. Thus, transactions in these nonrivalrous forms of property involve only partial alienation and therefore may give rise to reduced endowment effects. (The same is not true of certain works of fine art, which exist only as a single copy and are therefore fully rivalrous both as legal rights of ownership and as physical objects. In such a case, transfer of the work usually results in full alienation.)

We set out to determine whether and to what extent endowment effects attend transactions in nonrivalrous creative works. As we explain in more detail below, for purposes of this experiment we conceive of the value of an IP right as a probabilistic measure of the right's likelihood of returning rents. ${ }^{86}$ In this sense, IP rights function as weighted lottery tickets, with the rights associated with high-quality works more heavily weighted (and hence more valuable) than for those associated with poor-quality works. Because prior research has demonstrated endowment effects associated with lottery tickets, ${ }^{87}$ it seems reasonable to think that they will also be associated with goods traded in probabilistically valued markets. Moreover, other studies have shown that the endowment effect is greater when subjects feel like they earned the good than when they have simply been given the good. ${ }^{88}$ The emotions associated with creating a good should be at least as strong as those associated with having earned a good; thus it seems likely that creators will particularly overvalue goods that they have created.

We anticipated that creators of new works would experience substantial endowment effects causing them to systematically overvalue their works compared with potential buyers of the works. Moreover, we speculated that creators would exhibit even greater valuation differences from buyers than would noncreators who were simply endowed with others' creative works. That is to say, we predicted that the magnitude of the endowment effect for creators would exceed that for mere owners of the works.

Assessing whether authorship or ownership of IP has a distinctive effect on an owner-creator's valuation of his work is extremely important, especially in the modern technological environment where the role of IP law has been increasingly discussed. Specifically, when debating whether current IP law efficiently allocates and structures legal rights, the potential role of endowment effects must be taken into ac-

86 Because we are interested solely in the economic model of IP, we bracket a variety of other "values" that might be associated with creation and ownership of IP, including prestige, attribution, personality, and tenure. In future experiments, we hope to measure the effects of these as well. On alternative values in IP, see Jennifer E. Rothman, Liberating Copyright: Thinking Beyond Free Speech, 95 CoRnell L. REv. 463, 464-65 (2010).

87 See supra notes $43-46$ and accompanying text.

88 See supra notes 48-49 and accompanying text. 
count. Current IP law relies on property rules and private transactions to allocate rights efficiently. Yet, if substantial endowment effects attend created goods, we must worry about the efficacy of private transactions. ${ }^{89}$ In particular, the Coase Theorem relies upon the assumption that parties value rights the same whether they are initially endowed with them or not. Consequently, contrary to one of the main presumptions of the Coase Theorem, initial entitlements could matter because the "rate of exchange between goods can be quite different depending on which is acquired and which is given up, even in the absence of transaction costs or income effects." ${ }^{90}$ As a result, we might overestimate the number of transactions that will take place because the owner of a right will typically value it more than will the potential buyer. Hence, instead of the right reliably ending up in the hands of the party that will use it most efficiently, it is much more likely that the party that is initially assigned the right will retain it. ${ }^{91}$

\section{II}

\section{Modeling AN IP Market}

To test our hypotheses about the existence of endowment effects for created property, we organized a series of experiments intended to simulate a market for buying and selling creative works. Because we are interested in the implications of endowment effects for economic accounts of IP law, we attempted to create an informal model of the types of transactions that occur when IP changes hands. Unlike traditional property law where transactions typically result in exchanges of tangible goods or land, most IP transactions involve exchanges of intangible rights of exclusion..$^{92}$ Whereas property rights in real or personal property derive their value primarily from use and exchange, the exclusive rights granted by IP law are, in essence, monopolistic opportunities for rent seeking from other potential users and licensors, among others. ${ }^{93}$ The general value of owning an IP right is the ability, granted by the statutory monopoly, to exact fees for use of the work over some period of time. The value of any particular IP right, then, is simply the probabilistic value of the rents that an owner can obtain

\footnotetext{
89 See Rachlinski \& Jourden, supra note 79, at 1552-53.

90 Tversky \& Kahneman, supra note 60, at 1039.

91 Kahneman, Knetsch \& Thaler, supra note 36, at 1339-40. As an example, in one set of studies on preserving land from development, seven times as much land would be preserved if the general public held the rights rather than if the land was originally deeded to the landowner and had to be purchased by the public. See Horowitz \& McConnell, supra note 41 , at 428 .

92 An exception would be transactions for works of fine art, where the object and the right change hands in the same exchange. We are thinking currently about ways to test valuation effects for this type of transaction.

93 See Landes \& Posner, supra note 10, at 17.
} 
from holding the right to a given work. ${ }^{94}$ Thus, we can measure the ex ante value of a copyright in a newly created work by multiplying the amount of money that the copyright holder could obtain through using, selling, or licensing the work by the probability that it will succeed in generating that money. ${ }^{95}$

Imagine the following situation: A publishing house can estimate with reasonable certainty that there is a market for novels worth $\$ 100$ million in profits. The publisher would like to capture some of that money and is considering purchasing the rights for one of two different novels. Novel $A$ is quite good, and the publisher believes that it has a $60 \%$ chance of successfully capturing the market. Novel $B$ is not as good, and the publisher believes it has only a $10 \%$ chance of capturing the market. Accordingly, a rational publisher would be willing to pay any amount less than $\$ 60$ million for the rights to Novel $A$ or any amount less than $\$ 10$ million for the rights to Novel $B$. The value of each novel to the publisher (or to the author) is simply the value of the total rents multiplied by the chance of returning them to the rightsholder.

Of course, actual markets do not exhibit this kind of binary success or failure. Instead, individual works may have a probability of capturing varying portions of a total market. It is worth noting, however, that the fundamentally probabilistic nature is unchanged and that for our purposes, creating a more ecologically valid market would be experimentally intractable. In addition, while in many markets determining these figures may prove difficult, there is reason to believe that a similar method of valuation operates in many markets for IP. ${ }^{96}$ Indeed, many movie studios appear to perform nearly identical calculations when deciding which films to make. ${ }^{97}$

94 Mark Lemley and Carl Shapiro have made a similar suggestion in the context of patent valuation. See Mark A. Lemley \& Carl Shapiro, Probabilistic Patents, 19 J. Econ. Persp. 75,81 (2005) (suggesting that patents can be thought of as lottery tickets). They note that patent valuation may be uncertain due to uncertainty about both the patent's commercial significance and its validity and scope. See id. at 76. Here, we are concerned solely about the former. See also Jonathan S. Masur, Process as Purpose: Costly Screens, Value Asymmetries, and Examination at the Patent Office, 3 J. Legal Analysis (forthcoming 2010) (manuscript at 20) (on file with authors), available at http://ssrn.com/abstract=1105184 (describing private and social values of patents).

95 The rents that can be extracted from the work effectively are the profits that can be generated through ownership of the IP right after subtracting for fixed costs of creation. On fixed versus marginal costs of creating IP, see Masur, supra note 94 (manuscript at 37). In addition, we are setting aside any benefits the author may receive beyond royalties, including increased prestige, salary, etc.

96 See John R. Allison et al., Valuable Patents, 92 Geo. L.J. 435, 437-39 (2004).

97 See Thomas H. Davenport \& Jeanne G. Harris, What People Want (and How to Predict It), 50 MIT Sloan Mgmt. Rev. 23, 29 (2009) (describing movie studios' use of neural network analysis to make predictions about a film's likelihood of market success). According to the website for Epagogix, one of the leading companies assisting movie studios in making risky decisions, "Investing in and developing the wrong film properties is the biggest 


\section{A. The Contest: "Eyes Closed"}

In an attempt to model this system while preserving maximal ecological validity, this experiment created a quality-based contest resulting in a payout of known value. We solicited subjects from the Charlottesville, Virginia area via fliers, e-mails, and online advertisements. Most of our subjects were undergraduate students at the University of Virginia (UVA); other participants were solicited from the broader Charlottesville community. ${ }^{98}$ All subjects were paid $\$ 15$ for their participation. The subjects were divided into three groups based on their order of scheduling: the first third became Authors; the middle third became Bidders; and the final third became Owners. ${ }^{99}$ Completion of the study required subjects to spend about thirty minutes in a computer lab on the UVA campus. Data collection lasted approximately two months.

\section{Contest "Eyes Closed" Method}

First, the Authors were invited to the lab in groups. Each Author was seated at a computer and asked to provide some demographic information. They were then told that they would be competing in a haiku-writing competition with nine other subjects. At the end, a poetry expert would choose the best poem and award its writer a $\$ 50$ prize. The subjects were given instructions on writing haikus along with a sample poem. They were then given time to compose their poems. After completing their poems, the Authors were told that there were an additional ten subjects-the Bidders-who would have an opportunity to buy the Authors' chance of winning the $\$ 50$ prize should their poem be chosen. Each Author was informed that her poem would be assigned to a Bidder who would indicate the highest amount of money (in whole dollars) that he would be willing to pay to purchase the Author's chance to win and that the Author should indicate (in whole dollars) the lowest amount that she would be willing to accept to sell her chance. The Author was told that if the Bidder's amount was higher than the Author's amount, the Bidder would pay the amount of the bid to the Author in return for the Author's chance

\footnotetext{
risk that faces studio heads. Parent companies and investor groups place studios under ever-increasing pressure to deliver Returns on Investment across an annual portfolio of films. Epagogix's approach helps management of this most critical financial risk through accurate predictive analysis of the Box Office value of film scripts." Epagogix, www.epagogix.com (last visited Sept. 25, 2010) (emphasis omitted).

98 The subjects included 207 women and 287 students. The subjects' mean age was 24, and their mode age was 22.

99 All of the subjects were recruited simultaneously, but they were scheduled for participation at different times. Additionally, the experiment took place in "rounds" with groups of thirty. Accordingly, we feel confident that the subjects were not placed into groups in a fashion that might bias our results.
} 
at the prize money. The Authors were reminded in italics that they were only exchanging their chance to win the money and that the poem itself, which would be e-mailed to them, would still be theirs. We hoped that this reminder would help focus Authors' attention solely on the poem's value as an entry in the Contest rather than on any personal or use value that they might attach to it. Each Author then entered a WTA and answered some follow-up questions including how they would rate their poem and their predictions of its probability of winning the prize. ${ }^{100}$

After the data from the Authors had been gathered, Bidders were brought into the computer lab. The Bidders were told that the experimenters were holding a contest between ten poems written by other subjects for a $\$ 50$ prize. They were informed that they would be shown one of the poems and that they would have the opportunity to purchase that poem's chance of winning the prize. ${ }^{101}$ They were told to indicate the highest amount of money that they would be willing to pay the poem's author to purchase the poem's chance of winning the $\$ 50$ prize. If the amount they indicated was equal to or greater than the amount that the Author indicated, they would pay the Author the amount indicated. The Bidders then entered a WTP and answered the same follow-up questions.

Finally, the group of Owners was brought into the lab. They were told that the experimenters were hosting a $\$ 50$ poetry contest. They were told that they would be assigned one of the ten poems in the contest and that they would have an opportunity to sell their chance to win to another subject acting as a Bidder. The instructions given to the Owners about the bidding were similar to those given to the Authors. Each Owner was randomly assigned one of the poems previously written by an Author. The Owners then entered a WTP amount and answered the same follow-up questions.

\section{Contest "Eyes Closed" Results}

We observed a significant gap between the WTA of Authors and Owners and the WTP of Bidders. On average, the minimum amount that Authors would accept to transfer their chance of winning the contest was $\$ 22.90$ (with 40 Ps Authors $=23.88$ ). For Owners, the compa-

100 In our follow-up questions, we asked the subjects (1) to indicate why they chose the amount they did, (2) the probability that their poem would win the prize, and (3) a series of questions about their abilities as creative artists.

101 For simplicity's sake, we chose to make symmetrical the information available to buyers and sellers of creative works, with each group having identical knowledge about the nature of the market. In many IP markets, however, the buyers of IP rights (e.g., publishers, movie studios, etc.) will have substantially greater information about the market. Our experimental protocol is designed to work with asymmetrical markets as well, and we hope to publish that data soon. 
rable figure was $\$ 21.23$ (with 40 Ps Owners $=20.80$ ). These amounts are within the range of standard error, and so the difference between them is not statistically significant at a .05 confidence level. The Bidders' average WTP, at $\$ 10.38$ (with 40 Ps Buyers $=8.50$ ), was lower by an amount that clearly is statistically significant at that same confidence level versus the mean valuations of both Authors and Owners. ${ }^{102}$ Indeed, the WTA/WTP gap observed in this experiment is quite large-more than two to one-especially considering that the property at issue is nonrival and the experimental protocol involved the possibility of only partial alienation (i.e., alienation of the possibility of winning the contest, rather than the poem itself).

\section{B. The Contest: "Eyes Open"}

In an attempt to learn more about the psychological mechanisms underlying our findings, we performed a second experiment based on the initial Contest experiment. In the second experiment, however, instead of just being shown the poem that they were allowed to buy or sell, subjects were shown all ten poems that would be competing in the contest. We hypothesized that if quality judgments were affecting subjects' valuations, the subjects' relation to the poem might differentially affect those judgments. We predicted that viewing the competition would decrease the quality ratings and valuations of Owners and Bidders but that those of Authors would remain largely unaffected.

Our findings did not confirm these hypotheses. We observed no statistically significant changes in the behavior of subjects in any of the roles. In short, additional information seemed to have no effect on the WTA/WTP gap. The minimum amount that "Eyes Open" Authors would accept, on average, to transfer their chance of winning the contest was $\$ 20.18$. For Owners, the comparable figure was $\$ 23.95$. The Bidders' average WTP was, at $\$ 9.17$, lower by an amount that clearly is statistically significant at the .05 confidence level versus the mean valuations of both Authors and Owners. Again, the WTA/ WTP gap observed in this round of the experiment is quite large-

102 Contest: Eyes Closed results including all 52 participants:

A one-way Analysis of Variance (ANOVA) revealed a significant effect of role, $f(2153)=14.04, p<.0005$, with follow-up $t$ tests showing that Bidders' mean valuations were significantly lower than those of both Authors, $t(102)=4.92, p<.0005$, and Owners, $t(102)=4.57, p<.0005$. Authors' and Owners' valuations did not significantly differ, $t(102)<1$.

Contest: Eyes Closed results including only 40 participants:

A univariate ANOVA revealed a significant effect of role, $f(2117)=17.15, p<.0005$, with follow-up $t$ tests showing that Bidders' mean valuations were significantly lower than those of both Authors, $t(78)=5.62, p<.0005$, and Owners, $t(78)=5.18, p<.0005$. Authors' and Owners' valuations did not significantly differ, $t(78)<1$. 
more than two to one. These results are not significantly different from those in the "Eyes Closed" Contest. ${ }^{103}$

We have summarized the results for our "Eyes Closed" and "Eyes Open" contest conditions in the figures below. Both figures illustrate a significant gap between seller and buyer valuations as well as the absence of a significant difference between author and owner valuations and between the "Eyes Open" and "Eyes Closed" conditions.

Contest: Eyes Closed vs. Eyes Open

\begin{tabular}{|c|c|c|c|c|}
\hline \multirow[b]{2}{*}{ Role } & \multicolumn{2}{|c|}{ Eyes Closed } & \multicolumn{2}{|c|}{ EYES OPEN } \\
\hline & $\begin{array}{l}\text { Mean Value } \\
\text { Assigned to } \\
\text { Poem }\end{array}$ & $\begin{array}{c}\text { Standard } \\
\text { Error }\end{array}$ & $\begin{array}{c}\text { Mean Value } \\
\text { Assigned to } \\
\text { Poem }\end{array}$ & $\begin{array}{c}\text { Standard } \\
\text { Error }\end{array}$ \\
\hline Author & 22.90 & 2.05 & 20.05 & 2.19 \\
\hline Owner & 21.23 & 1.84 & 23.45 & 2.30 \\
\hline Buyer & 10.38 & 1.51 & 9.21 & 1.30 \\
\hline
\end{tabular}

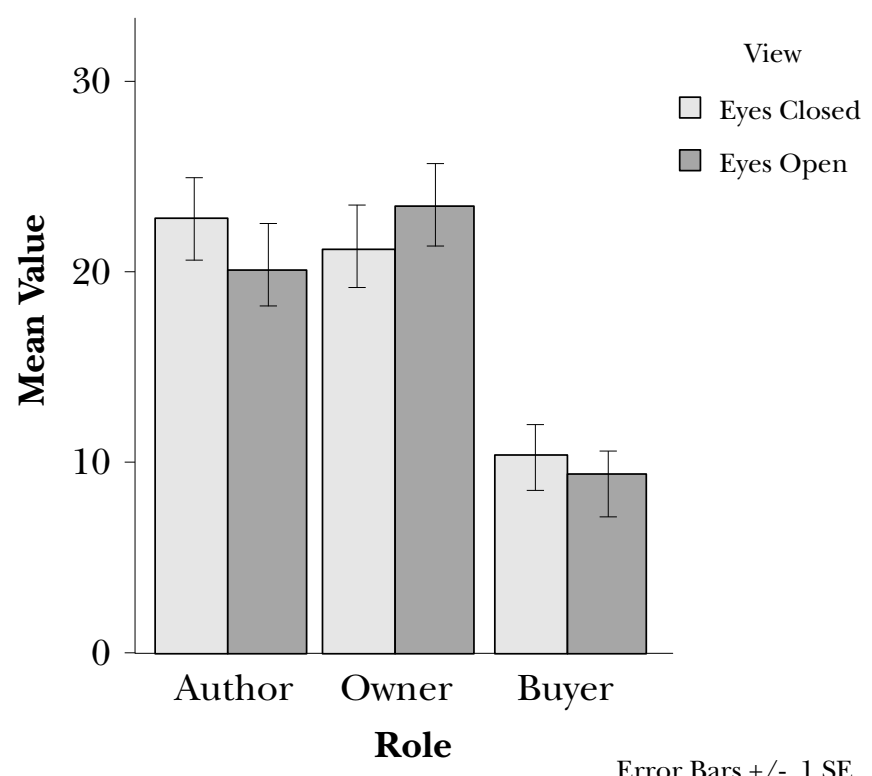

103 We analyzed the Contest: Eyes Open data using an Analysis of Covariance (ANCOVA) with "rating of poem," "rating of oneself as poet," and "predicted probability of winning" as covariates. The covariate "predicted probability of winning" was significantly related to mean valuation, $f(1114)=9.71, p<.005$. After controlling for the effects of the three covariates, we again found a significant effect of role on mean valuations, $f(2114)=12.45, p<.0005$. Follow-up $t$ tests showed that Buyers' mean valuations were significantly lower than both Authors' and Owners', $t(78)=4.20, p<.0005, t(78)=5.20$, $p<.0005$, respectively. Authors and Owners, however, did not significantly differ in their mean valuations, $t(78)=-1.16, p>.05$. 


\section{The Lottery: "Blind"}

The difference between Author and Owner WTA and Bidder WTP that we perceived in our initial study might have occurred for a number of reasons. Perhaps the Authors and Owners, being initially endowed with the chance to win the prize, were motivated by a strong sense of regret aversion, which caused them to insist on greater compensation for the risk of missing out on the prize. ${ }^{104}$ Previous studies have shown owners of lottery tickets to be unwilling to part with their tickets for rational monetary values because they fear the disutility they will experience if their ticket turns out to be the winner. ${ }^{105}$ Perhaps additionally or alternatively, the Authors and Owners might be subject to a version of "optimism bias" or "wishful thinking," making them feel as though their chances of winning the prize were greater than they actually were. ${ }^{106}$ For example, lottery participants often know the odds against them but nonetheless believe that they personally are more likely to win than the odds suggest. ${ }^{107}$

\section{Lottery Method}

In order to test whether the WTA/WTP gaps were the result of either or both of these phenomena, we conducted a follow-up study that substituted the quality-based contest of the initial study for a random lottery. If loss aversion or optimism bias were motivating the Authors' and Owners' higher asking prices, the WTA/WTP gaps in the initial and follow-up studies should have been identical. As with the initial study, participants were recruited from the Charlottesville area and assigned to the same three conditions of Author, Bidder, and

104 See Dale T. Miller \& Brian R. Taylor, Counterfactual Thought, Regret, and Superstition: How to Avoid Kicking Yourself, in Heuristics and Biases: The Psychology of Intuitive JudgMENT, supra note 30 , at 367, 372-73. The labeling of this possible source of endowment effect as "regret aversion" does not, of course, tell us much about where the posited regret comes from. Those who hew to a personality justification for IP rights-i.e., the theory by which IP rights are justified by the ways in which creative goods both reflect and help form an author's or inventor's identity-would maintain that regret aversion reflects the creative good's intertwining with its owner's identity. We express no view here and note simply that the source of anticipated regret is an interesting question for future consideration.

105 See Bar-Hillel \& Neter, supra note 64, at 17.

106 See David A. Armor \& Shelley E. Taylor, When Predictions Fail: The Dilemma of Unrealistic Optimism, in Heuristics and Biases: The Psychology of Intuitive Judgment, supra note 30, at 334, 334 ("By a number of metrics and across a variety of domains, people have been found to assign higher probabilities to their attainment of desirable outcomes than either objective criteria or logical analysis warrants.”); Zlatan Krizan \& Paul D. Windschitl, The Influence of Outcome Desirability on Optimism, 133 Psychol. Bull. 95, 95 (2007).

107 See Ellen J. Langer, The Illusion of Control, 32 J. Personality \& Soc. Psychol. 311, 311-13 (1975). Another possible explanation for the reluctance to exchange lottery tickets is that owners of the tickets superstitiously believe that by selling a ticket, they are tempting fate and increasing the likelihood that their former ticket will win. See Jane L. Risen \& Thomas Gilovich, Another Look at Why People Are Reluctant to Exchange Lottery Tickets, 93 J. Personality \& Soc. Psychol. 12, 12 (2007). 
Owner. In the follow-up study, however, instead of being told that the poems would be entered into a contest judged according to quality, the subjects were informed that one of the ten poems would be selected at random to receive the $\$ 50$ prize. All other aspects of the study were identical.

\section{Lottery Results}

We again observed a significant gap between the Authors' and Owners' WTA and Bidder WTP. The minimum amount that Authors would accept, on average, to transfer their chance of winning the contest was $\$ 18.93$. For Owners, the comparable figure was $\$ 15.98$. The difference between mean Author and Owner valuations rests on the borderline of statistical significance at the .05 confidence level. The Bidders' average WTP, at $\$ 5.60$, was lower by an amount that clearly is statistically significant versus the mean valuations of both Authors and Owners. ${ }^{108}$ Indeed, the WTA/WTP gap observed in this experiment is even larger than in the contest condition-more than three to one versus Authors and almost three to one versus Owners. Importantly, however, for each of the roles, valuations in the Lottery were significantly lower than they were in either of the contest scenarios. These figures illustrate our results in the lottery condition.

\section{LOTTERY}

\begin{tabular}{|c|c|c|}
\hline Role & $\begin{array}{c}\text { Mean Value } \\
\text { Assigned to Poem }\end{array}$ & Standard Error \\
\hline Author & 18.92 & 2.21 \\
\hline Owner & 15.98 & 2.13 \\
\hline Buyer & 5.60 & .98 \\
\hline
\end{tabular}

108 The lottery data were analyzed using an ANCOVA with "rating of poem," "rating of oneself as poet," and "predicted probability of winning" as covariates. The covariate "predicted probability of winning" was significantly related to mean valuation, $f(1114)=4.77$, $p<.05$. There was also a significant effect of role on mean valuations after controlling for the effects of the three covariates, $f(2114)=11.68, p<.0005$. Follow-up $t$ tests revealed the same pattern found in the Contest: Eyes Closed condition: mean valuations given by Buyers were significantly lower than those given by both Authors and Owners, $t(78)=5.51$, $p<.0005, t(78)=4.43, p<.0005$, respectively. The difference in valuations between Authors and Owners failed to reach significance, $t(78)<1$. 


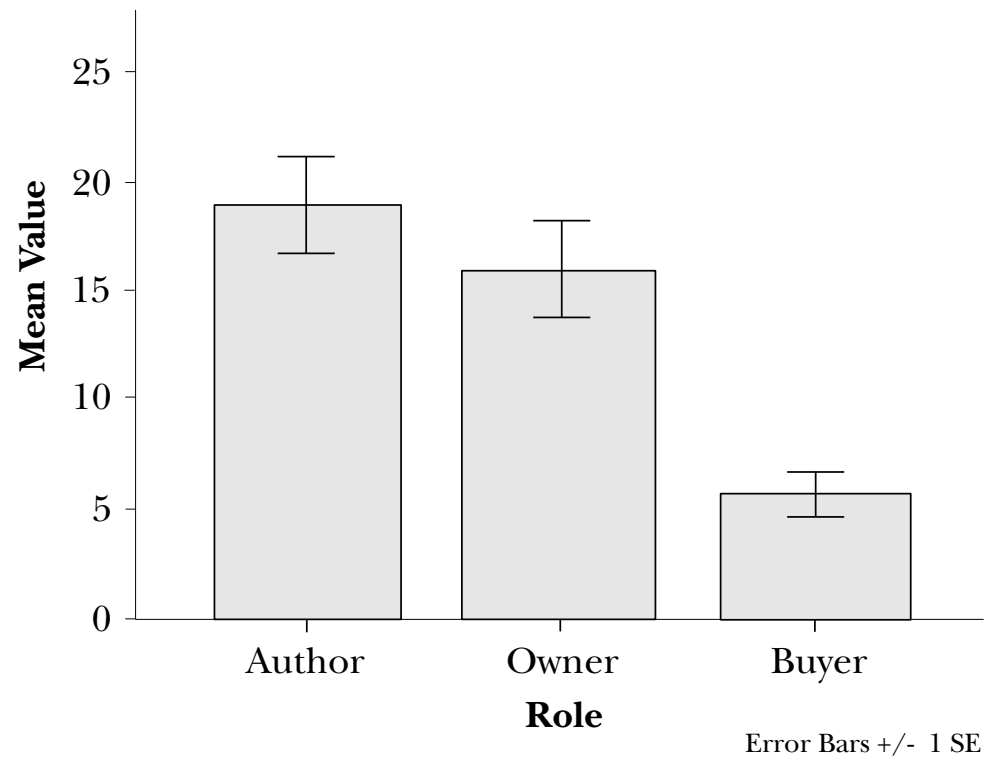

In summary, across all of our experiments, we detect substantial valuation asymmetries between Authors and Buyers of poems. Authors generally request more than twice the amount to sell their poems than Buyers are willing to pay for them. This discrepancy suggests the existence of a considerable endowment effect for IP. In addition, we found no significant differences between the valuations of Authors and Owners. Finally, in the lottery condition where poem quality should not have mattered, Authors' and Owners' valuations were lower than they were in the contest conditions but were still substantially higher than classical probability and economics would predict. In the following two Parts, we explore both the psychological mechanisms that drive our results and their implications for IP law and policy.

III

Understanding Creators' Behavior: INTERPRETING OUR Results

In order to generate normative proposals from our findings, it is first necessary to interpret the results and to isolate, as much as possible, the psychological effects generating them. A variety of causes of WTA/WTP discrepancies might exist, each with different legal implications. ${ }^{109}$

109 See Korobkin, supra note 13, at 1242 ("In order to draw normative conclusions about legal policy in light of the endowment effect, . . . it is important to understand what causes individuals to place a higher value on an entitlement if they are endowed with it than if they are not...."). 
We begin by noting that the subjects in our experiment generally followed the prescriptions of classical probability theory-as their beliefs about the likelihood of winning the prize rose, so did their valuations of the poems. ${ }^{110}$ Similarly, poems that were rated higher in the contest were more highly valued by Authors, Owners, and Bidders alike. Thus, we feel confident that the subjects understood the task and behaved accordingly.

Although the subjects' valuation responses generally tracked their subjective assessments of the probability of winning the prize, their valuations diverged considerably from the objective probabilities of winning. In a contest with 10 poems and a $\$ 50$ prize, each poem would have a baseline $10 \%$ chance of winning and, accordingly, an expected value of $\$ 5(10 \% \bullet \$ 50=\$ 5)$. Depending on the quality of the poem compared with its competitors, its expected value would increase or decrease from the $\$ 5$ baseline. But because the contest is a zero-sum game, the mean valuation of the 10 poems would remain $\$ 5$. And although the subjects do not have perfect knowledge of their weighted chance to win, any errors that they make should randomly distribute around the mean. For the lottery, because poem quality will not affect probability of winning, the expected value of each poem remains $\$ 5$. Accordingly, the "rational actor" account of the market would predict similar valuation means around $\$ 5$ for all subjects in both the Contests and the Lottery. ${ }^{111}$

This explanation is, of course, not what we see. Contest Authors and Owners want more than $\$ 20$ to sell their chance to win the prize, and Contest Buyers are willing to pay about $\$ 10$ to buy a chance. These valuation asymmetries are particularly large, especially considering the nature of the endowment. Recall that Authors and Owners were not alienating the entire poem but only their chance to win the prize, keeping with the nonrival nature of IP licenses and transfers. Thus, results demonstrating such a large WTA/WTP gap for only partial alienation suggest a rather strong endowment effect. These results confirm that endowment effects attend transactions in creative goods. These results also confirm that endowment effects attend transactions in nonrival goods. Of particular interest, the nonrivalrousness of the poems did not appear to reduce substantially the size of the pricing anomaly observed-more than two to one in the contest condition and approximately three-to-one in the lottery condition. Not only are these substantial valuation anomalies by any measure, but they also are especially striking given that the experimental protocol involves

110 See supra notes 103 and 108.

111 Authors and Owners might be slightly higher than $\$ 5$ and Bidders slightly lower due to strategic bargaining, but (1) bargaining was not possible in this study and (2) the differences would be minor. 
(a) a payout of known value in exchange (b) for only partial alienation of nonrival property.

These results raise a deeper question: What causes the endowment effect we observe in our study? We believe that our results are the effect of both regret aversion and an optimism/ownership bias. Regret aversion stems from people's desire to avoid feeling like they acted foolishly and could have made a better decision. People often anticipate that they will feel unhappy if they choose to act in a way that produces an undesirable result; consequently, they are willing to pay or demand a premium to avoid that feeling. ${ }^{112}$ Thus, people may demand more than a lottery ticket's expected value to sell it in order to avoid or compensate for the regret they would feel if it turns out that they had sold the winning ticket. Separately, people have a well-documented tendency to prefer things associated with themselves and, accordingly, to value those things more highly. In some cases, this ownership effect may become apparent in the overly sanguine estimates people make of their own chances of success-a phenomenon we refer to here as "optimism bias." Even though people understand the objective probabilities of marriages ending in divorce or of receiving grades at the bottom of the curve, they overestimate their own likelihood of success.

Our data suggest that both regret aversion and optimism bias have considerable roles to play in valuation asymmetry. In many endowment effect studies, regret aversion and ownership/optimism effects are confounded such that the individual contributions of each are undetectable. ${ }^{113}$ Our experimental design provides a method for distinguishing the effects of regret aversion and optimism bias. We can compare subjects' predicted probabilities of winning with the valuation that they assigned their poem in both the contest and lottery conditions. To begin with, subjects in all of the roles in the contests substantially overestimated their chance of winning the prize (Authors $=28 \%$; Owners $=26 \%$; Buyers $=16 \%$ ), thus illustrating that optimism bias drives some of the result. Importantly, the divergences from the objective probabilities in the contest are much higher than they are for the lottery where quality should not count at all (Authors $=17 \%$; Owners $=12 \%$; Buyers $=11 \%$ ). Accordingly, it seems as if all of the roles in the contest and the Authors in the lottery feel unduly confident in their chances of winning the prize. When subjects are confronted with uncertain probabilities of success, they express elevated

112 See Gilbert et al., supra note 65, at 350.

113 See Morewedge et al., supra note 58, at 948. 
confidence in their chance of winning. Additionally, stronger relationships with the goods correlate with higher levels of optimism. ${ }^{114}$

It is possible, however, that excessive optimism is not the only factor that accounts for the valuation asymmetries. To determine if this is the case, we can look at the subjective expected value of a poemi.e., the predicted probability of winning multiplied by the amount of the prize. If the subjective expected value of a poem (predicted probability - prize) is equivalent to value assigned to the poem, any difference from the objective expected value is likely due only to optimistic assessments of probabilities. But if the value assigned to the poem exceeds the subjective expected value, the difference may result from subjects insisting on a premium to avoid feelings of regret. The data support the latter explanation. For Authors and Owners in the Contest, the assigned value substantially exceeds the expected value based on their predicted probability of winning (for Authors, \$21 $\$ 14=\$ 7$; for Owners, $\$ 22-\$ 13=\$ 9) .{ }^{115}$ An Author who thought she had a $28 \%$ chance of winning the Contest should value it at $\$ 14$; the difference between her WTA (\$21) and this number could indicate the amount of money $(\$ 7)$ that it would take to compensate her for the disutility she would feel if she sold the winning poem. ${ }^{116}$ This suggests that Authors' and Owners' valuations are products both of overly optimistic predictions and regret aversion. ${ }^{117}$ Interestingly, for Buyers, the assigned value and the expected value are quite similar yet greater than the amount dictated by the objective probability, suggesting that Buyers experience optimism bias but not regret aversion. This finding is consistent with other experimental evidence suggesting that regret aversion is stronger when people act (e.g., sell the winning lottery ticket) than when they fail to act (e.g., not buy the winning lottery ticket), which of course is another way in which the distribution of initial entitlements tends to drive behavior that does not conform to the classical rational choice model. ${ }^{118}$

Finally, it is worth pointing out an important aspect of our results. A surprisingly large number of Authors and Owners in the Contest reported a WTA price of $\$ 50$, indicating that they refused to sell their chance to win the prize. Although it may seem wildly irrational to

114 We speculate that the higher-than-expected probability ratings of Contest Bidders are based on feeling that the poem they have been assigned is "theirs" in some way.

115 These figures blend the "Eyes Open" and "Blind" contest valuations.

116 We are not suggesting that subjects make these calculations explicitly or consciously.

117 The same regret aversion is visible in the Lottery condition. Mean ValuationSubjective Expected Value (for Authors, $\$ 17-\$ 8=\$ 9$; for Owners $\$ 16-\$ 6=\$ 10$ ). These results are consistent with other studies showing that owners of lottery tickets insist on a premium price to avoid the feeling of regret. See supra note 65 and accompanying text.

118 See Thomas Gilovich \& Victoria Husted Medvec, The Experience of Regret: What, When, and Why, 102 Psychol. Rev. 379, 380-81 (1995). 
refuse to sell a $10 \%$ chance at $\$ 50$ for even $\$ 45$, these data may point to the high regard that some people have for property rules that protect their right to reject transfers.

Having examined the psychological effects underlying our results, a couple of curious issues remain. First, our prediction that $\mathrm{Au}-$ thors would exhibit greater valuation biases than Owners failed to materialize. We anticipated that Authors would have a greater attachment to the poems they had written than Owners would to poems that had been given to them, resulting in higher WTA values. So what happened? We have three thoughts. One possibility is that the creativity effect that we initially posited simply may not exist. This explanation is possible, but subsequent research supports the opposite conclusion. ${ }^{119}$ A second possibility is that the lack of a difference is more likely an artifact of our experimental design. In most real-world settings, creativity primarily is internally motivated by the desire to create (contrary to most economic accounts), ${ }^{120}$ whereas in our experiment, Authors were told to write their poems and did so without the "spark" of creative motivation. Additionally, the size of the creative effort in our study was quite small. The five to ten minutes that subjects took to write their three-line poems is not equivalent to the effort that goes into painting a portrait, writing a concerto, or filming a movie. At this level of creativity, we may simply have missed important aspects of real-world authors' preferences that might distinguish authors from third-party owners. In fact, data from a follow-up experiment indicate that when the creative endowment is larger and internally motivated, a significant "creativity effect" appears. ${ }^{121}$

We also note that our Owners, who were meant in our experimental design to stand in for the intermediaries or agents who serve authors and inventors in real markets, differ from these actors in one very important way-unlike real-world agents, our Owners lack any meaningful market experience. To the extent that previous scholarship suggests that market experience reduces endowment effects (at least for goods that trade regularly and have ready substitutes-conditions which, we should emphasize, do not characterize our poems),

119 See Christopher Buccafusco \& Christopher Sprigman, The Creativity Effect, 77 U. CHI. L. REv. (forthcoming 2010).

120 See Anne Barron, Copyright Infringement, "Free-Riding" and the Lifeworld 15 (London Sch. of Econ. \& Political Sci., Law, Soc'y \& Econ., Working Paper No. 17, 2008), available at http://ssrn.com/abstract=1280893; Tushnet, supra note 12, at 521 .

121 The follow-up experiment used the same methodology as this one, but studied painting students at an art school. The students entered paintings into a contest with a 1in-10 chance to win $\$ 100$. As with this study, we observed a significant endowment effect between Owners (mean valuation \$40.67) and Buyers (mean valuation \$17.88). However, Painters' valuations (mean valuation $\$ 74.53$ ) were even greater still. See Christopher Buccafusco \& Christopher Sprigman, The Creativity Effect, 77 U. CHI. L. Rev. (forthcoming 2010). 
we did not observe any such reduction in our data for our inexperienced Owners. This finding would tend to make the endowment effects that the Authors and Owners exhibited appear more similar to one another than they are likely to be in real-world markets. ${ }^{122}$

Another unexpected result was the similarity between valuations in the "Eyes-Closed" and "Eyes-Open" versions of the Contest. We expected that subjects with more information about the relevant market would make more "rational" choices about their odds of winning. Yet allowing the subjects to see the other poems in the competition did not significantly affect the results. A couple of explanations present themselves. Because much of the valuation bias seems to arise from regret aversion, subjects' fear of feeling regret may not decrease with additional information about the competition. Perhaps more likely is the possibility that the combination of regret aversion and optimism bias is simply too strong to be eliminated by the additional information.

In summary, our experiment demonstrates a large valuation asymmetry between creators of new works and potential buyers. Authors and Owners in the Contest value their work at a rate more than four times higher than rational choice theory would predict and more than twice as high as Bidders are willing to pay. Authors and Owners in the Lottery value their work at a rate more than three times higher than rational choice theory would predict and approximately three times as high as Bidders are willing to pay. These substantial discrepancies are particularly strikingly considering that Authors and Owners were selling nonrival goods for which feelings of both ownership and the regret associated with loss (because "loss" does not involve full alienation) might have been lower. Additionally, the subjects' exaggerated valuations appear to be the results of both optimism/ownership biases and regret aversion. Poem authors are overly optimistic about their chances of winning the prize and are willing to pay a substantial premium to avoid feeling regret about having sold the winning poem. Finally, two expected methods of debiasing creators may have limited or no effect. We did not find an effect either for increased market information (the "Eyes Open" condition) or the use of third-party intermediaries (the Owners). We caution against reading too much into this last conclusion-our Owners lack the type of market experience that real-world agents possess. Use of intermediaries likely provides some benefit, but given the magnitude of

122 Another difference between our Owners and market intermediaries cuts the other direction. Unlike our Owners, who were merely assigned a poem, many real-world intermediaries are likely to have a close relationship with the works they are selling. They may have chosen the works, or the works may have been produced by friends, associates, or colleagues. These relationships are likely to strengthen the endowment effect even as market experience undercuts it. 
the pricing anomalies that we observed, we doubt that they are a panacea.

IV

\section{Implications for Intellectual Property Law and Policy}

Having explored the likely psychological mechanisms that account for our results, in this Part we turn to their implications for IP law and policy. Although valuation asymmetries may exist, the law may not always seek to eliminate them. In general, only when we are confident that the asymmetries result from cognitive biases and not just idiosyncratic preferences should we consider attempts at debiasing. Similarly, debiasing techniques have costs, both in their implementation and in their effects on other social values. ${ }^{123}$ Only when the benefits of debiasing exceed its costs should the law take action. First, we examine whether the optimism and regret aversion at the heart of our valuation asymmetries are indeed welfare-reducing biases. Concluding that they are to some considerable extent, we next turn to methods for mitigating their effects.

\section{A. Do the Endowment Effects We Observe Lead to Inefficiency?}

To begin the task of assessing the importance of our findings for IP law and policy, we must first address an overarching conceptual question: Are the endowment effects we observe in our study inconsistent with the rational choice model? Or, to put it another way, are our observed endowment effects likely to lead to outcomes that the rational choice model would recognize as inefficient? There is an argument that endowment effects-at least those that arise as a result of regret aversion-are in fact not anomalous but, rather, are consistent with a more fully realized account of the rational choice model. A person's desire to avoid feelings of regret, this argument maintains, is simply another preference, and when people factor their regret aversion into a pricing decision, they are acting according to what the rational choice model would predict if it had a better account of their preferences in the first place. Thus, regret aversion may widen the gap between sellers' minimum WTA and buyers' maximum WTP and reduce the number of competed transactions but result neither in a suboptimal number of transactions nor any inefficiency. Rather, the outcome will faithfully reflect the parties' preferences, which are simply taken as a given. ${ }^{124}$

123 See Jonathan Klick \& Gregory Mitchell, Government Regulation of Irrationality: Moral and Cognitive Hazards, 90 Minn. L. Rev. 1620, 1623 n.11 (2006).

124 In order to make this argument, of course, supporters of the rational choice model would have to relax the assumption regarding context-independent preferences. Subjects 
We believe that our study and other relevant scholarship show this argument to be weak in the IP context for two principal reasons. First, a substantial increment of the endowment effect that appears in our study's contest condition results from optimism bias rather than regret aversion. The contest conditions are, in our view, the most ecologically relevant branch of our study-in most IP markets, quality is an important criterion of success. And endowment effects that grow out of optimism bias lead to inefficiency and behavior departing from what the rational choice model would predict. Refusing to sell a $\$ 5$ lottery ticket for anything less than $\$ 20$ because you inaccurately believe it has a higher chance to win is inefficient. This is true whether we think of optimism bias as a form of imperfect information or simply as a failure to respond to the information that is available.

Our study suggests that optimism bias arises from the latter cause-our subjects did not behave very differently when presented with more complete information in the "Eyes Open" version of our contest condition. But whatever the cause, the tendency of would-be sellers to systematically overestimate a proposed transaction's likely payout leads them to formulate a minimum WTA that exceeds the WTA they might indicate if they were able to engage in a more neutral calculation of the odds of success. And because optimism bias affects sellers more than buyers (we see this differential effect reflected in our data), we can expect this bias to lead to a suboptimal number of transactions. This point is important, not least because IP markets characterized by optimism biases are subject to a systematic form of mispricing that our study suggests is difficult to address even by providing subjects with more information about the likelihood of success. Our "Eyes Open" condition gave subjects more complete information about their likelihood of success than participants in a real-world IP market are ever likely to enjoy, yet we observed only marginal reduction of subjects' optimism bias.

This brings us, secondly, to the increment of the endowment effect we observed in our study that we assign to regret aversion. Does this portion of the effect lead to inefficiency? ${ }^{125}$ The answer here is less clear, but we believe there is a strong argument that large endowment effects arising from regret aversion create distortions from within the rational choice framework. According to the rational choice model, when people make risky choices in activities like gambles and lotteries, they make estimates based on how the possible outcomes are likely to make them feel. It might be that in our

will feel regret most strongly when in the position of a seller giving up, thus this updated model would have to allow for valuation asymmetry based on ownership status.

125 See Jonathan Baron, Thinking and Deciding 280 (4th ed. 2008) (describing different possibilities for whether valuations based on regret are rational). 
experiment, Authors and Owners accurately estimated that the negative emotion they would feel at having sold what turned out to be the winning poem would not be sufficiently offset by gain from the poem's probabilistic value. ${ }^{126}$ For example, they might have believed that on some measure of well-being or happiness, the regret that they would feel selling the winning poem would equal -8 and that the benefit they would receive from selling the poem for $\$ 5$ would be +2 . Thus, they might correctly believe that they would need to sell the poem for at least $\$ 20$ to offset their regret. If people make these predictions accurately, regret aversion may not create additional problems for the rational actor model.

So how good are people at making predictions about future hedonic states? A growing body of social scientific research suggests that the answer is "not very good at all." 127 When predicting how they will feel after an event, people tend to overestimate both the intensity and the duration of their negative emotional responses. ${ }^{128}$ People fail to account for their ability to adapt to new situations and thus predict that bad experiences will feel worse and last longer than they actually do. These "affective forecasting errors" have been demonstrated for a variety of events including losing a romantic partner, failing an exam, and becoming disabled. ${ }^{129}$ In addition, a recent experiment indicates that affective forecasting errors exist for risky gambles as well. ${ }^{130}$ Subjects predicted that losing the gamble would have significantly more emotional impact than winning, even though no actual difference was observed. ${ }^{131}$ They also substantially overestimated the extent to which losing would make them feel bad. ${ }^{132}$ Although the gamble differs in some ways from our experiment, ${ }^{133}$ there is good reason to think that if people are paying premiums to avoid regret (by inflating their WTA amounts), then they are failing to maximize either their wealth or their happiness. ${ }^{134}$

\section{B. The Debate Between Property Rules and Liability Rules}

If endowment effects lead to inefficiency, then our study suggests that organizing IP law as a set of strong property rights (i.e., rights to exclude) might impose substantial costs. These costs must be evalu-

\footnotetext{
126 See id.

127 See Bronsteen, Buccafusco \& Masur, supra note 2, at 9-12.

128 Timothy D. Wilson \& Daniel T. Gilbert, Affective Forecasting: Knowing What to Want, 14 Current Directions Psychol. Sci. 131, 131 (2005).

129 See id. at 131-33.

130 See Kermer et al., supra note 63, at 650-51.

131 Id. at 651

132 Id

133 For example, the emotional impact of seeing someone else win a prize with "your" poem might be greater than that of simply losing a standard bet of similar magnitude.

134 See Kermer et al., supra note 63, at 652.
} 
ated as part of the wider debate regarding whether the law should be reorganized around liability rules (i.e., rules that allow users access without the need to ask permission but require payment). ${ }^{135}$ If the wide disparities between Buyers' willingness to pay and Authors' and Owners' willingness to accept that we found in our study characterize a range of IP transactions, then parties seeking to license or otherwise transfer ownership of creative works will face substantial negotiation costs arising from the need to bridge these large differences in valuation.

This should be troubling; the efficacy of rights transfer via negotiation is crucially important to IP law as it is currently structured. In both the copyright and patent contexts, initial rightsholders (usually authors in the case of copyright ${ }^{136}$ and inventors ${ }^{137}$ in patent) often are not particularly well positioned to exploit their own work. ${ }^{138}$ The novelist's prospects for successful commercialization of his work depend on the very different skills and resources of the publisher. The same is true of the engineer and the venture capitalist in the patent context.

Given the gap between initial entitlement and commercial exploitation, an efficient IP law must provide a smooth transition between the initial rightsholder and the eventual transferee or licensee. Little empirical evidence, however, bears on whether the current law creates an environment in which such transfers may be accomplished with reasonable efficiency. ${ }^{139}$ Thus far, the law's preference for property rules is based primarily on a presumption that markets and armslength negotiations will allocate rights more efficiently than the alternative (i.e., a legal regime based in liability rules in which users are

135 See Merges, supra note 18, at 1293-94 (favoring property rules); A. Mitchell Polinsky, Resolving Nuisance Disputes: The Simple Economics of Injunctive and Damage Remedies, 32 Stan. L. Rev. 1075, 1112 (1980) (favoring property rules); J.H. Reichman, Legal Hybrids Between the Patent and Copyright Paradigms, 94 Colum. L. Rev. 2432, 2439-42 (1994) (favoring liability rules).

136 Copyrights vest in a work's natural author unless the work is recognized as a "work made for hire"-i.e., either the work of an employee acting within the scope of his or her employment or a "sponsored work" within certain categories and denominated a work made for hire via a written instrument signed by both parties-in which case initial ownership of the work vests in the employer. See 17 U.S.C. $\$ 201$ (b) (2006) (defining "works made for hire").

137 U.S. patent law contains a strong "inventorship" requirement-only the actual inventor may apply for and receive a patent. See 35 U.S.C. $\$ 102$ (f) (2006).

138 See Merges, supra note 18, at 1307 ("Assigning an entitlement to the most efficient holder is generally not possible in the complex field of intellectual property, where creative works have many uses requiring multiple transactions.").

139 In fact, the evidence that does exist suggests that IP rights often hinder efficient transactions. See Michael Heller, The Gridlock Economy: How Too Much Ownership Wrecks Markets, Stops Innovation, and Costs Lives 1-23 (2008) (describing the bargaining problems associated with anticommons effects). 
free to take and where the price of use is set not via private negotiation but by a legislature, court, or government agency). ${ }^{140}$

Our study undercuts that presumption. It is true that liability rules require nonmarket price setting, which is beset by its own costs and is likely to lead to misallocation in some cases. ${ }^{141}$ On the other hand, IP's strong property rules may sometimes lead to significant pricing anomalies that hinder transactions and impose separate inefficiencies that liability rules may not create. ${ }^{142}$ The valuation asymmetries that we have identified add a significant and previously unrecognized layer to the transaction costs associated with IP bargaining. The parties' very different starting positions will result in both higher bargaining costs and fewer otherwise valuable transactions. ${ }^{143}$ The inefficiencies that property rules create are neither different in kind nor necessarily less severe than those that liability rules create. Worse, they are systematic in one direction-overvaluation and failed bargains-whereas the valuation errors under liability rules are more likely to be distributed symmetrically on both sides of the optimal price (i.e., nonmarket pricing is as likely to produce undervaluation as overvaluation). ${ }^{144}$ If this idea is correct, then symmetrical mispricing may not create substantial ex ante disincentives to engage in the creation of new works, for even if the creator understands that mispricing is likely under a liability rule, there is an equal chance of over- and undercompensation.

As a consequence, if our confidence in IP law's preference for strong property rules is to be sustained, it must be done on the basis of better evidence about the costs and associated inefficiencies of negotiation versus the costs and associated inefficiencies of liability rules. These questions are empirical-not theoretical or ideological-and the answers may vary for different types of creativity and for different markets. To make a start, we need more studies inquiring into whether pricing anomalies attend IP markets in a variety of circumstances, how large the WTA/WTP gaps are likely to be, and what can be done to shrink them. ${ }^{145}$

140 See Merges, supra note 18, at 1308. Current IP law does include some liability rules. For example, under U.S. copyright law one may re-record a musical composition (i.e., make a "cover" version) without the need to ask permission, subject to a royalty set by a government agency. See 17 U.S.C. $\$ 115$ (establishing compulsory license for "mechanical reproduction" of copyrighted musical compositions).

141 See Merges, supra note 18, at 1299.

142 See Rachlinski \& Jourden, supra note 79, at 1549-50.

143 See Russell Korobkin, Who Wins in Settlement Negotiations?, 11 Am. L. \& Econ. Rev. 162, 196 (2009) (showing that the distance between parties' initial offers is inversely correlated with the likelihood of successful bargaining).

144 We are indebted to Mark Lemley for this point.

145 It is possible that the sense of ownership and attachment that creators feel might cut both ways in affecting IP licensing and transfer. While the endowment effect that we 


\section{The Effects of Royalties and Formalities on IP Valuation}

When thinking about the value of property or liability rules for IP, we must also be concerned about the ways in which IP rights are transferred and created. Private and public ordering might drastically affect actual outcomes. Accordingly, this Section first turns to the role royalty contracts may play in mitigating the valuation asymmetries that we discovered. Although little research has been done on the theory or practice of royalty bargaining, it is possible that royalty contracts might lessen the effects of endowment. Next, this Section considers the use of various formalities in copyright and patent law to diminish the impact of endowment effects by restricting property-rule remedies to works that meet some substantial valuation threshold.

We suspect that the relative efficiency of property rules versus liability rules will vary depending on the particular form of creativity at issue and, importantly, the value of the work that is the subject of a particular transaction. For copyrighted and patented works with significant commercial value, parties may use various tools to reduce the effect of valuation anomalies. The parties may use an intermediary to strike deals. If the intermediary has substantial market experience and the good has readily available substitutes, we might expect a reduction in the gap between WTP and WTA and a consequent increase in the number of transactions to a point closer to optimality.

Additionally, although most of the situations discussed above are based on outright purchases or licenses of IP, not all IP deals are structured in this fashion. Parties may instead structure licenses as running royalties, which may serve to mitigate endowment effects. The running royalty_an arrangement where periodic payments are made according to some percentage of sales or revenues ${ }^{146}$ - is a way of effectively "agreeing to disagree" over the value of a creative work. In cases where an author or inventor believes that the work is likely to produce substantially more revenue than the purchaser believes, use of a running royalty may allow both parties to structure a deal that matches their expectations and reduces inefficiencies caused by optimism bias or regret aversion.

We should emphasize that we cannot be sure how effective running royalties will be at mitigating endowment effects. Because surprisingly little empirical research exists on the negotiation of royalties,

have shown likely inhibits IP transfers, many creators may be motivated by more intrinsic desires for publication and reputational benefits that could promote transfers. For example, creators might be so motivated just to see their work in print or to have their names attached to it that they might be willing to accept less than market value for their work. This is an empirical question that we hope to test in future research.

146 See Ted Hagelin, Valuation of Patent Licenses, 12 Tex. Intell. Prop. L.J. 423, 426-41 (2004) (describing various methods for calculating patent royalties). 
it is difficult for us to predict how endowment effects will affect royalty bargaining. ${ }^{147}$ It is possible, as we have noted, that royalties might reduce the effects of optimism bias by allowing the parties to move forward without having to resolve their differences about the likely return on the transaction. But it also seems plausible that the substantial differences between the parties' estimates of likely success will continue to hinder their ability to agree on an acceptable split of the profits; the seller's inaccurately high estimate of the likelihood of the work's success may feed into a conviction that he deserves a more advantageous split of projected revenues. Similarly, royalty payments may protect the creator's feelings of attachment to the work because she will still be compensated if the work is successful, thereby mitigating regret aversion. Or, the parties may continue to disagree over valuation because the seller's valuation impounds an increment to compensate for anticipated loss that is nowhere reflected in the buyer's valuation. Thus, the seller is likely to demand a rate for a running royalty that is calculated to produce a payment larger than the buyer will be willing to provide. Indeed, these questions present another level of complexity: in many IP contexts, the royalty rate will not be subject to bargaining because it will be set by industry norms. Again, it is difficult to predict for settings where bargaining is impossible or unlikely whether the inability to bargain and the strength of norms will undermine endowment effects. Inability to bargain may result in an exercise of buy-side market power that partially or wholly offsets endowment effects. Or, it may simply result in a negotiation failure.

Even if the use of running royalties can play a role in mitigating endowment effects, it is very unlikely to be a complete answer to the problem of valuation. Running royalties are expensive to negotiate, implement, and administer. They require ongoing monitoring and periodic payments. As a result, running royalties are appropriate only for transactions that are valuable enough to bear the transaction costs of the running royalty arrangement. Importantly, the transactions that are not valuable enough to warrant the expense of royalties are also likely to be those for which endowment effects are most prominent-those created by one-time individual players. And while individually these creations might not generate impressive value, their aggregate value is substantial-witness, for example, the litigation and settlement disputes surrounding the Google Book Search project. There, Google and the Authors Guild have attempted to bind a huge number of individual authors in a class settlement agreement that would give Google rights to use the works of the class authors in its

147 We hope that future experiments will illuminate this unexplored area. 
online tool for searching the contents of books. ${ }^{148}$ In order for the Google search tool to be valuable, it must encompass as many published books as possible; absent the settlement—and at the time of this writing it is far from clear that the settlement will be approvedGoogle would be obliged either to negotiate with a huge number of individual authors or rely on a chancy fair use argument. Were Google to follow the negotiation route, each individual deal may be for little value, but the aggregate value would be quite large. In this light, the Google Book Search settlement can be seen as an attempt to construct-through a creative use of the class action mechanism-an effective private liability rule for Google's use of books. ${ }^{149}$ We express no view on the desirability of the Google Book Search settlement. Along with our results, however, it does suggest that it may be desirable to restrict IP law's property rules only to works that are likely to trade above a certain minimum value.

In the patent context, this work is already done to some extent. The U.S. Patent and Trademark Office grants patents only after an examination procedure to ensure that rights attach only to inventions that are novel, nonobvious, and useful. ${ }^{150}$ The process does not always work-every year many patents are granted that should not have been. The examination procedure nonetheless does provide a screen that is useful for our purposes-because it is expensive (on average, $\$ 22,000$ ), the patent examination requirement tends to filter out inventions that are commercially valueless. ${ }^{151}$ The same is true of the patent system's maintenance fees: all utility patents are subject to maintenance fees that must be paid 3.5, 7.5, and 11.5 years from the patent's date of issue. ${ }^{152}$ The fees are substantial and rise at each increment $\left(\$ 980, \$ 2,480\right.$, and $\$ 4,110$, respectively). ${ }^{153}$ Maintenance fees effectively move out of the patent system inventions that may ini-

148 See generally Google Book Search Library Project, Ass'N OF ReSEARCH Libraries, http:// www.arl.org/pp/ppcopyright/google/ (last visited Oct. 5, 2010) (providing an overview and the full text of the proposed settlement).

149 In this way, it mirrors some of the bargaining to liability rules that Merges discusses. See Merges, supra note 18, at 1296-1302.

150 See 35 U.S.C. $\$ 101$ (2006).

151 See Masur, supra note 94 (manuscript at 2). Masur writes, "The high costs of prosecuting a patent force inventors to determine ex ante whether the property rights they might acquire are genuinely worth the expense. This ex ante private cost creates a type of costly screen: the patent applicant must decide whether the expected benefits of obtaining a patent, discounted to present value, exceed the costs of navigating the patent office process. This price barrier forces potential applicants to draw upon private information about the value of their inventions, information that the patent office is otherwise unable to obtain." Id. at 2-3 (citation omitted).

152 See 35 U.S.C. \$ 41(b) (2006) (establishing maintenance fees).

153 For the complete fee schedule, see United States Patent and Trademark Office Fee Schedule, United States Patent and Trademark Office, http://www.uspto.gov/web/offices/ ac/qs/ope/fee2009september15.htm (last visited Sept. 25, 2010). 
tially have had significant commercial value but have turned out not to. We should be clear that we are not denying that there are commercially valueless patents-there are many. They tend, however, not to be licensed. Patents that are licensed tend to have some non-de minimis commercial value.

In the case of copyright, the same is not true-or, to be more accurate, is no longer true. ${ }^{154}$ The U.S. copyright system traditionally made the grant and maintenance of copyright subject to a set of mandatory requirements that together became known as copyright's "formalities." At copyright's inception in 1790 and for almost 200 years thereafter, the initial grant of copyright was subject to a requirement either that the author enter the work on the official copyright registry or that he mark all published copies with notice of copyright, or both. In addition, the copyright system traditionally required authors to renew (effectively, to re-register) their works after a relatively brief initial term. Failure to comply with registration or notice formalities meant that the work entered the public domain without a copyright ever arising. Failure to comply with the renewal requirement meant that the work moved into the public domain after the expiration of the copyright's initial term. ${ }^{155}$ In addition, applicants had to pay fees to register and renew a copyright, with these fees serving as a filter-similar to those operating today in the patent system-that tended to restrict copyright to works with some substantial commercial value. ${ }^{156}$

Under pressure from other countries, the Copyright Act of 1976 removed mandatory formalities from the law. Copyright now arises automatically and indiscriminately whenever a creative work is fixed in any tangible medium of expression. ${ }^{157}$ There is now no screen that limits the application of copyright's strong property rights to works with some substantial commercial value. As a consequence, manyindeed, the vast majority of-works that are subject to copyright's property rule have no substantial commercial value. Until recently, that hardly would have mattered-the economics of distribution meant that few uses could effectively be made of works with low commercial value. But as the Google Book Search project and other efforts involving mass digitization-such as the Internet Archive's Million Books Project—show, in the current environment of very low-

154 See Jonathan Masur \& David Fagundes, Costly Intellectual Property 2 (Feb. 20, 2010) (unpublished manuscript) (on file with author) (arguing that the lack of costly screening mechanisms in copyright might be socially beneficial).

155 For a summary of the details and effect of the traditional system of copyright formalities, see generally Christopher Sprigman, Reform(aliz)ing Copyright, 57 STAN. L. REv. 485 (2004).

156 See id. at 502.

157 See 17 U.S.C. § 102(a) (2006) (defining copyrightable subject matter). 
cost digital distribution of works, a wide range of uses of works of otherwise low commercial value are possible. These uses, which may produce social value, may nonetheless be insufficiently valuable to bear the significant negotiation costs required to overcome the valuation anomalies arising from endowment effects (in addition to other negotiation costs and the risk of strategic behavior). And again, these transactions are likely to involve the kind of sellers most susceptible to valuation biases.

We are not free, however, simply to reintroduce into copyright law the traditional formalities. As a signatory to the Berne Convention-the leading international agreement governing copyright lawthe U.S. is forbidden from implementing formalities that affect the "exercise and enjoyment" of copyright. ${ }^{158}$ Additionally, the traditional formalities, which remove all rights in a work upon a finding of noncompliance, are squarely within the forbidden territory.

We can, however, obtain many of the benefits of the traditional formalities without offending Berne. One direct way would be to construct an effective liability rule through a revised set of copyright remedies. Current copyright law provides both compensatory remedies and disgorgement of any profits the infringer realizes that are related to the infringement, ${ }^{159}$ as well as readily available injunctive relief. ${ }^{160}$ In addition, current law provides the option of significant statutory damages (i.e., damages awarded without regard to any showing of actual harm) and an award of attorney's fees in infringement actions involving works registered prior to commencement of the defendant's infringement. ${ }^{161}$ Copyright's remedies provisions are aimed squarely at deterrence-even for unregistered works, the combination of compensation, disgorgement, and readily available equitable relief are consistent with copyright's strong property rule.

But there is nothing inevitable about inconsistency between a legal rule and the remedies available for its breach. Indeed, copyright's sister legal regime, patent, features not only substantive rights that are structured as strong property rules but also remedies provisions that are oriented more directly at compensation rather than deterrence. The Patent Act, in particular, limits monetary damages to a "reasona-

\footnotetext{
158 See Sprigman, supra note 155 , at 547.

159 See 17 U.S.C. \$ 504(b) (providing for award of actual damages).

160 See id. $\$ 502$ (providing for injunctive relief).

161 See id. $\$ 504$ (c) (providing for statutory damages); $i d . \S 505$ (providing for costs and attorneys fees).
} 
ble royalty." 162 The award may be trebled for willful infringement, ${ }^{163}$ but courts rarely invoke this power. ${ }^{164}$ Similarly, awards of attorney's fees are limited to "exceptional cases" and are, relative to the rate at which they are awarded in copyright infringement lawsuits, rarely ordered. ${ }^{165}$ Although the Patent Act also provides for preliminary and permanent injunctions, ${ }^{166}$ since the Supreme Court's opinion in eBay Inc. v. MercExchange, L.L.C., ${ }^{167}$ it has been clear that injunctions are not available as a matter of course; rather, the plaintiff must establish the need for relief beyond monetary compensation according to traditional rules of equity. ${ }^{168}$ In short, patent's remedies regime does not faithfully reflect patent's strong property rules-indeed, patent law provides remedies that, at least in cases where damages are limited to those required to compensate the plaintiff and equitable relief is held inappropriate, are effectively equivalent to a liability rule.

Our results suggest that at least for unregistered works, copyright's remedies regime should move closer to that of patent. Current copyright law already limits the award of statutory damages and attorney's fees to works registered before the commencement of the infringement at issue. If we treat registration as a rough proxy for works that possess some commercial value, we could improve copyright's remedies regime by also conditioning the availability of disgorgement and injunctive relief upon timely registration. There is reason to believe that even very low-cost formalities could have a substantial effect on the nature and extent of copyright protection. These formalities would return the U.S. to an opt-in regime for copyright. Although economic theory predicts that the nature of the default rule will not affect choice outcomes when the costs of choosing are minimal, a growing body of empirical data suggests that defaults are incredibly

162 See 35 U.S.C. \$ 284 (2006) ("Upon finding for the claimant the court shall award the claimant damages adequate to compensate for the infringement, but in no event less than a reasonable royalty for the use made of the invention by the infringer, together with interest and costs as fixed by the court.").

163 Id.

164 The Patent Act provides that courts have discretion to impose damages up to three times the amount of the infringement, $i d$., but the courts have long held that an award of enhanced damages requires a showing that the defendant's infringement was willful. See, e.g., Jurgens v. CBK, Ltd., 80 F.3d 1566, 1570 (Fed. Cir. 1996) (holding that bad faith infringement-a type of willful infringement-is sufficient to establish the defendant's culpability for enhanced damages). Recently, the Federal Circuit-the federal appellate court that has the principal role in judicial interpretation of the Patent Act-made clear that a finding of willfulness required evidence that the defendant's infringing conduct was objectively reckless. See In re Seagate Tech., LLC, 497 F.3d 1360, 1371 (Fed. Cir. 2007).

165 With respect to attorney fees, the Patent Act makes clear that they may be awarded only in "exceptional cases." 35 U.S.C. § 285.

166 See id. § 283.

167547 U.S. 388 (2006).

168 See id. at 390. 
"sticky."169 Thus, even if the costs of opting into full copyright protection were close to zero, many authors might still choose not to participate. Accordingly, copyright would not have to adopt the expensive screens that patent law uses to achieve a significant shift in the nature of ownership. The result of such a shift would be to expose low-value works to the effective equivalent of a liability rule. The low-value works are precisely those for which various means for reducing endowment effects-e.g., use of intermediaries or running royalties-are least likely to be effective, due to their high cost relative to the low value of the transaction.

\section{Behavioral Biases and the Market Failure Theory of Fair Use}

In copyright law, the fair use doctrine exists to exempt from liability some uses of a work that would otherwise infringe an owner's copyright. Although a variety of accounts of fair use doctrine exist, ${ }^{170}$ one of the leading scholarly theories of fair use focuses on the doctrine's application to market failures that prevent socially beneficial uses. ${ }^{171}$ On this account, the existence of markets for creative works generally ensures that secondary users are able to license works when such licensing will lead to beneficial uses. In a number of situations, however, markets may fail to function properly, impeding valuable transfers. When this impediment occurs, courts should apply the fair use doctrine to enable secondary uses. ${ }^{172}$

Previous accounts of the market failure theory have focused on failures that arise from market barriers, bargaining costs, externalities, and anti-dissemination motives. ${ }^{173}$ Our experiment suggests that, in addition, otherwise mutually beneficial transfers may not occur due to biased valuations of creative works even where functioning markets exist. If authors and owners of copyrighted works make irrational demands that prevent the licensing of their work, secondary works with surplus social value may not get made. For example, the owner of a musical composition copyright might demand, in part due to an endowment effect, an irrational amount of money to license her song to another user who wants to use part of the song as a sample in a new

\footnotetext{
169 See Thaler \& Sunstein, supra note 73, at 8; Korobkin, supra note 6, at 664-66.

170 See, e.g., Edward Lee, Technological Fair Use, 83 S. CAL. L. REv. 797, 817-18 (2010).

171 See Wendy J. Gordon, Fair Use as Market Failure: A Structural and Economic Analysis of the Betamax Case and its Predecessors, 82 Colum. L. Rev. 1600, 1604-05 (1982).

172 See id. The market failure theory is not uniformly accepted. See Lydia Pallas Loren, Redefining the Market Failure Approach to Fair Use in an Era of Copyright Permission Systems, $5 \mathrm{~J}$. Intell. Prop. L. 1, $48-57$ (1997); Glynn S. Lunney, Jr., Fair Use and Market Failure: Sony Revisited, 82 B.U. L. Rev. 975, 975-79 (2002); Wendy J. Gordon, Market Failure and Intellectual Property: A Response to Professor Lunney, 82 B.U. L. REv. 1031, 1031-36 (2002); Raymond Shih Ray Ku, Consumers and Creative Destruction: Fair Use Beyond Market Failure, 18 BERKELEY TECH. L.J. 539, 557-64 (2003).

173 See Gordon, supra note 171, at 1627-35.
} 
work. In such a case, if a court could reliably detect the presence of significant endowment effects, it might consider declaring the secondary use fair and thus not infringing.

As William Patry notes, much of the rhetoric surrounding IP, and especially that coming from IP-producing industries, portrays copyrights and patents as naturally endowed property rights in intellectual creations. ${ }^{174}$ This rhetoric distracts from the widely held academic and judicial view that IP is instead a regulatory mechanism for enhancing social welfare through the imposition of costs and benefits to creators and the public. IP law gives creators certain exclusive rights to their works, but these rights are subject to limitations that protect the rights of the public and subsequent creators. To the extent that IP encourages creators to think of their works as "property," Patry suggests that creators will view use of their work without permission as "a personal attack" and "immoral." 175 Moreover, their instinctual attachment to their created works-an attachment based on an endowment effect that Patry implies and that we demonstrate here-prevents creators from appreciating the regulatory nature of IP and understanding the necessity of others' uses. ${ }^{176}$ Accordingly, creators' feelings of attachment are likely to undermine efficient market pricing resulting in suboptimal secondary use. Doctrines like fair use might be utilized to allow secondary uses that would not otherwise have occurred due to overvaluation of creators' "property."

For courts to more reliably detect the presence and assess the likely magnitude of endowment effects, however, there must first be more research modeling a variety of IP transactions, both in terms of different forms of creativity and in different institutional settings where intermediaries and community norms may have differing effects on valuation. Even if courts face difficulties in determining whether endowment effects frustrate socially productive licensing in particular cases, the mere threat of fair use declarations based on irrational valuations may help de-bias owners to begin with. When a court declares secondary uses as fair, original owners receive no compensation; under this regime, regret-averse owners might actually be encouraged to bargain. Moreover, the threat of fair use as a corrective for irrational valuation may help undermine the "propertization" of IP law and refocus creators' attention on its essentially regulatory character. As we begin to learn more about the existence of endowment effects in IP markets, we should be able to recognize situations

174 William Patry, Moral Panics and the Copyright Wars 113 (2009). "The effort to describe copyright as property is intended to invoke ancient entitlement to powerful rights of exclusion . ..." Id.

$175 \quad I d$. at 131.

176 Id. at 131-32. 
in which valuation biases lead to market failure. ${ }^{177}$ That knowledge will be valuable to courts when determining whether to allow certain uses.

\section{Conclusion}

In this experiment we have established the likely presence of substantial endowment effects in transactions involving IP. This finding is significant for two reasons. First, the endowment effects literature to date has focused only on transactions involving property that test subjects simply receive, rather than create. Our study extends the literature to show that the pricing anomalies referred to as the endowment effect extend to created goods. Second, our study shows that endowment effects attend transactions in nonrival property. Again, this addition is novel to the literature, which previously only discussed these pricing anomalies in the context of fully rivalrous property. Most IP transactions involve nonrival goods.

In addition to establishing the effect's existence for IP transactions, our experiment shows that the pricing anomalies we observed arise from a combination of optimism bias and regret aversion. We believe that endowment effects arising from both causes lead to inefficiencies within the rational choice framework.

Finally, we advance some suggestions for how our results might affect IP policy. Most broadly, we believe that our results should inform the ongoing debate over whether IP law is best structured around property rules or liability rules. Additionally, we argue that our results point toward the advisability of copyright re-formalization, which is best achieved via reformulation of copyright's remedies provisions to limit owners of works that are unregistered (and therefore presumptively of low commercial value) to the effective equivalent of a liability rule. Finally, our findings should inform copyright's fair use doctrine. Many courts considering the fair use defense already base their analysis, in part, on the presence of significant transaction costs that lower the likelihood that the parties would have negotiated a license and therefore make fair use more appropriate. In light of our findings, courts should consider whether a license for the use at issue in a particular case would likely be subject to significant endowment effects. If so, it is less likely that the parties would have struck a deal as an alternative to the defendant's unauthorized use, therefore making a finding of fair use more appropriate.

177 Something like this scenario appears to be happening in the market for soundrecording licensing for music sampling. See Peter DiCola, Sequential Music Creation and Sample Licensing 1-5 (Northwestern Law \& Econ. Research, Paper No. 10-06, 2010), available at http://ssrn.com/abstract=1553890. 
Future research will, we hope, extend this experiment in a variety of directions. Will Authors' valuations differ from those of Owners' when the creative effort is more substantial and externally motivated? What roles do royalties and bargaining play in mitigating valuation asymmetries? Might those asymmetries increase if we introduce other valuable aspects of creative property, such as attribution, prestige, and the like? These and other questions remain unanswered. 
